Eskişehir Osmangazi Üniversitesi

Sosyal Bilimler Dergisi

Haziran 2020, 21(1), 187-213

DOI: 10.17494/ogusbd.763605

\title{
Tarihi Yapılarda Sürdürülebilirlik ilkesi Bağlamında Eskişehir Odunpazarı Evleri
}

\author{
Rümeysa Reyna ERŞAN, Deniz DEMIRARSLAN*
}

Tarihi Yapılarda Sürdürülebilirlik İlkesi Bağlamında
Eskişehir Odunpazarı Evleri

Özet

Sürdürülebilirlik kavramı 1972'de Birleşmiş Milletler Konferansı'nda ortaya çıkmış, "varolma yeteneği" anlamına gelen bir kavramdır. Pek çok alanda kullanılan kavram mimaride yapıların gelecek nesillere bozulmadan aktarılabilmesini ifade eder. Özellikle günümüzdeki hızlı nüfus artışılla birlikte çoğalan çarpık kentleşmeyle sürdürülemez hale gelen, gelecek nesillere aktarılabilmesi oldukça önemli olan tarihi yapılar; farklı kültürlere ve uygarlıklara ev sahipliği yapmış, geçmişle gelecek arasında köprü vazifesi görmektedirler. Bu çalışmada tarihi yapıların sürdürülebilirliği üzerine bilgilendirme yapılmış, Eskişehir Odunpazarı Evleri'ndeki Yağcızade Konağı, Dalyancı Konağı ve Hafız Ahmet Efendi Konağı örnekleriyle incelenmiştir. Bu çalışmada Niteliksel Araştırma Yöntemleri kullanılımıştır. Literatür Taraması ile birlikte yerinde inceleme ve röportajlar yapılarak restorasyon çalışmalarıyla ilgili pek çok bulguya ulaşıımış, Odunpazarı Evleri'ne yapılan yenileme çalışmalarının sürdürülebilirliğe katkıları üzerine bir değerlendirme yapılmıştır.

Anahtar Kelimeler: Tarihi Yapı, Sürdürülebilirlik, Koruma, Restorasyon

Makale Türü: Araştırma
Eskişehir Odunpazarı Houses in the Context of
Sustainability Principle in Historical Buildings

Abstract

The concept of sustainability which emerged at the United Nations Conference in 1972, means "ability to exist". The concept used in many fields implies that structures can be transferred to future generations intact. Especially, the historical structures that are unsustainable by the urbanization that has increased with the rapid population growth today, and which can be passed on to the next generations; They have hosted different cultures and civilizations and act as a bridge between the past and the future. In this study, information was given on the sustainability of historical buildings, and analyzed with examples from Yağcızade Mansion, Dalyancı Mansion and Hafız Ahmet Efendi Mansion in Eskişehir Odunpazarı Houses. Qualitative Research Methods were used in this study. Along with the Literature Review, many findings regarding the restoration studies were reached by conducting on-site examinations and interviews, and an evaluation was made on the contribution of renovation works of Odunpazarı Houses for sustainability.

Keywords: Historical Structure, Sustainability, Conservation, Restoration

Paper Type: Research

\section{Giriş}

Birleşmiş Milletler Konferansı ile bir terim olarak ortaya çıkan Sürdürülebilirlik; kısaca "daimî olma yeteneği" anlamına gelmektedir. Sürdürülebilirlik kavramı yaşam, sağlık hizmetleri, eğitim, tasarım ve mimari gibi pek çok farkı alanda kullanılmaktadır. Mimari yapılarda sürdürülebilirlik kavramı yapının bünyesinde yaşayan toplumların ve uygarlıkların kültürleri, gelenek görenekleri ve yaşayış biçimlerine, bunların yanı sıra bulunduğu konumun iklim koşullarına ve coğrafi durumuna, maruz kaldığı tüm çevresel faktörlere aldırmadan varlığını sürdürebilme olarak tanımlanmaktadır.

* Rümeysa Reyna ERŞAN, Kocaeli Üniversitesi, İç Mimarlık Bölümü, reyna.ersan@gmail.com , ORCID ID /orcid.org/00000002-0893-4065 , Deniz DEMIRARSLAN, Doç.Dr., Kocaeli Üniversitesi, İç Mimarlık Bölümü , demirarslandeniz@gmail.com ,ORCID ID /orcid.org/0000-0002-7817-5893 
Bir başka deyişle sürdürülebilirlik yapının var olma savaşı olarak özetlenebilir. Özellikle günümüzde bu var olma savaşı, şehirlerdeki hızı nüfus artışı ve bilinçsiz yapılaşma gibi etkenlerden dolayı oldukça zor bir hal almıştır. Gittikçe zorlaşan var olma savaşının bu denli önemli olmasının sebebi toplumların kültür varlıklarının gelecek nesillere aktarılmasının o toplumun tarihini, sosyolojisini, geleceğini aydınlatmasıdır. Sürdürülebilirlik bağlamında, özellikle korunması ve gelecek nesillere aktarılması oldukça önemli olan başlıca yapılar tarihi yapılardır.

Tarihi yapılar toplumların ekonomik, sosyal ve kültürel birikimleri ile inşa edildikleri dönemin kentsel ve mimari üslubunu yansıtan birer belge ve sembol niteliği taşımaktadır. Geçmişte yapıların işlevselliğini sürdürmek, doğal afet, yangın ve savaşlarda yıkılan kısımlarını yeniden inşa ederek biçimsel bütünlüğünü korumak için onarımlar yapılırken, günümüzde tarihi yapılar toplumun belli bir dönemdeki kültürel kimliğini, sosyal yaşamını, mimari tekniklerini gösteren birer belge niteliği taşımaları nedeniyle koruma amaçlı onarılabilmektedir (Aydın ve Şahin, 2018: 65). Tarihi yapıların onarımının ve yenileme çalışmalarının belirli standartlar çerçevesinde yapılması gerekmektedir. Bu çalışmada sürdürülebilirliğinin sağlanması amacıyla izlenebilecek yollar belirlenmiş, sürdürülebilirlik yöntemleri çıkarılmış ve bu yöntemler ışı̆̆ında doğru uygulamaların nasıl yapılacağına dair bir yol çizmek, gün geçtikçe zorlaşan yapıların var olma savaşını belirli sürdürülebilirlik yöntemleri ile kolaylaştırmak amaçlanmıştır. Belirtilen amaçlar doğrultusunda Eskişehir Odunpazarı Evleri örnek olarak ele alınmıştır. Eskişehir Odunpazarı Evleri Eskişehir'in ilk yerleşim yeri olup; tarihi ve kültürel açıdan şehir için oldukça büyük bir önem teşkil etmektedir. Tarihi evler geçirdiği pek çok tarihi ve siyasi olay ile birlikte, bir dönem şehrin gözde merkezi iken önemini yitirmiş ve ölü bir bölge haline gelmiştir. Çalışmada Odunpazarı Evleri'nin geçirdiği süreçler detaylı bir şekilde ele alınmış, bölgenin yeniden canlandırıması ve sürdürülebilirliğinin sağlanması adına, geçirdiği restorasyon çalışmalarının incelemesi yapılmışırı. Odunpazarı Evlerinin geçirdiği restorasyon ve yenileme süreci değerlendirilmiş, literatür taraması dışında yerinde inceleme yapılmıs, Odunpazarı Belediyesi yetkilileri ile röportaj yapılarak bilgi ve veri aktarımı sağlanmış, bu yöntemler sonucunda restorasyon çalışması aşamalarını belgeleyen birçok veriye ve sözlü bilgiye ulaşılmıştır. Veriler toplandıktan sonra koruma ve yenileme çalışmalarında doğru müdahalenin yapılabilmesi adına yol gösterici olması hedeflenerek sürdürülebilirlik yöntemlerine ilişkin çıkarımlar yapılmış, Eskişehir Odunpazarı Evlerinde gerçekleştirilen restorasyon çalışmalarındaki müdahalelerin nasıl yapıldığı, hangi yöntemlerin kullanıldı̆̆ı, restorasyon öncesi ve sonrası karşılaştırması ile sonuç olarak doğru müdahalelerin yapılıp yapılmadığına dair bir değerlendirme yapılmıştır.

\section{Yöntem}

Tarihi yapılarda sürdürülebilirliğin sağlanması amacıyla uygulanan özellikle restorasyon ve benzeri sürdürülebilirlik çalışmalarında doğru müdahalelerin gerçekleştirilmesine, gerçekleştirilen uygulamaların ise doğruluk kriterlerinin belirlenmesine yardımcı olmak amacıyla sürdürülebilirlik yöntemlerinin ele alındığı çalışma kapsamında Eskişehir Odunpazarı Evleri restorasyon çalışmalarının incelemesi ile ilgili Eskişehir Odunpazarı Evleri ve tarihi yapılarda sürdürülebilirlik konularına üzerine pek çok veri içerdiği için öncelikle ; Atıcı (2017), Değirmenci ve Sarıbıyık(2015), Mahrebel(2006), Özüdoğru, Ertuğrul ve Manaz(2005), Sev, A. (2009), Uçkan ve Uçkan (2002), 
Yüksel,G. Kurtçu,H. Koçak,M. Aksoy,R. (2015) , Zeren, M.T. (2019). kitaplarından ayrıca Eskişehir Teknik Üniversitesi öğretim üyesi Prof.Dr.Meral Nalçakan'ın 1993 tarihinde yayınlanmış olan "Tarihi ve Kültürel Sürekliliğin Fiziksel Çevrede Değişime Yansıması ve Eskişehir Örneği” adlı doktora tezinden temel kaynak olarak yararlanılmıştır. Gerekli literatür taraması yapıldıktan sonra gözlem, doküman analizi ve birebir görüşme yapılması, aynı zamanda tarihi Odunpazarı Bölgesi'ndeki ikamet eden insanların niçin ve nasıl yerleştikleri sorularına cevap aranması bu çalışmada Niteliksel Araştırma Yöntemlerinin kullanılmasını gerektirmiştir. Çalışmada bölgeye yerleşilmesinin sebepleri, bölgede yaşanan tarihi ve sosyokültürel olayların ve deneyimlerin incelenmesiyle Fenomenoloji Yöntemi; özel bölge olarak Odunpazarı Bölgesi'nin örnek alınması, bölgenin tarihinden geçirdiği siyasi olaylara, kültüründen mimarisine kadar benzer pek çok konu ve durumun incelenmesiyle Örnek Olay Yöntemi; Bölgenin yerinde ziyaret edilerek, bölge mimarisinin sahada incelenmesiyle Saha Taraması Yöntemi ; önceden hazırlanan sorular ışığında Odunpazarı Evleri'nin restorasyon aşamalarıyla bizzat ilgilenen Odunpazarı Belediyesi yetkilileriyle bir röportaj ${ }^{\dagger}$ gerçekleştirilmesi ile Birebir Görüşme Yöntemi kullanılmıştır. Bu görüşme sonucunda Odunpazarı Evleri restorasyon çalışmaları ile ilgili sözel ve yazılı bilgilere, fotoğraf arşivinden fotoğraflara ulaşılmıştır (Tablo.1).

Tablo.1 - Problemin Tanımı ve Araştırma Yöntemi

\begin{tabular}{|c|c|c|}
\hline Problemin Tanımı & Gereksinim Duyulan Araştırmalar & Araştırma Yöntemi \\
\hline $\begin{array}{l}\text { Tarihi Odunpazarı } \\
\text { evlerine uygulanan } \\
\text { yenileme }\end{array}$ & $\begin{array}{l}\text { Odunpazarı Bölgesi'ndeki ikamet eden insanların } \\
\text { niçin yerleştikleri sorularına cevap aranması. }\end{array}$ & $\begin{array}{r}\text { Niteliksel Araştırma } \\
\text { Yöntemi }\end{array}$ \\
\hline $\begin{array}{l}\text { çalışmalarının } \\
\text { sürdürülebilirlik }\end{array}$ & $\begin{array}{r}\text { Çalışmada bölgeye yerleşilmesinin sebepleri, } \\
\text { bölgede yaşanan tarihi ve sosyokültürel olayların } \\
\text { ve deneyimlerin incelenmesi. }\end{array}$ & Fenomenoloji Yöntemi \\
\hline açısından & & \\
\hline $\begin{array}{l}\text { uygunluğunun } \\
\text { değerlendirilmesi. }\end{array}$ & $\begin{array}{r}\text { Bölgenin tarihinden geçirdiği siyasi olaylara, } \\
\text { kültüründen mimarisine kadar benzer pek çok } \\
\text { konu ve durumun incelenmesi. }\end{array}$ & Örnek Olay Yöntemi \\
\hline
\end{tabular}

Odunpazarı bölgesinin ve evlerinin yerinde ziyaret

Saha Taraması ve Birebir

edilerek, bölge mimarisinin sahada incelenmesi.

Görüşme Yöntemi

† Odunpazarı Belediyesi yetkilileri ile 2019 yılı Aralık ayı içerisinde birebir görüşme yapılmış, konuyla ilgili sözlü ve yazılı bilgiler elde edilmiştir. 


\section{Sürdürülebilirlik Kavramı}

Sürdürülebilirlik kavramı; üzerine yorum getiren muhtelif yazarlar tarafından "var olmak", "devam ettirmek", "sürdürmek", “...e katlanmak", "temin etmek”, "desteklemek” gibi anlamlarda kullanılmaktadır. Bu kavramlarla ifade edilmek istenen, bir sistem ya da yöntemin kendi kendini idame ettirebilmesi, sürdürebilmesi, bir şeyin yüküne katlanabilme becerisi ve kabiliyetidir. Daha genel ve geniş bir perspektiften bakıldığında sürdürülebilirlik, bir şeyin kendisini muhafaza edebilme, koruyabilme, varoluşunu devam ettirebilme becerisi ve yeteneğine tekabül etmektedir. $O$ halde bir ürün, bir faaliyet veya herhangi bir şey sürdürülebilir ise bahse konu olan şey yeniden kullanılabilir, yeniden tekrarlanabilir veya o şeyin bir biçimde geri dönüşümü mümkün olabilir (Şen vd., 2018: 5). Sev'in eserindeki (2009: 15) vermiş olduğu tanıma göre ise; sürdürülebilirlik durağan bir kavram olmayıp; tarihsel perspektif içerisinde toplumsal, ekonomik, sosyal ve kültürel koşullara bağlı olarak değişkenlik göstermektedir.

İsveç'in Stockholm kentinde düzenlenen 1972 Birleşmiş Milletler Konferansı'nda, ekonomik ve sanayileşme yönünden küresel kalkınmanın neden olduğu çevresel sorunların yanı sıra gelişmekte olan ülkelerin ekonomik ve sanayileşme bakımından gereksinim duydukları kaynak arayışları arasında bir denge politikası oluşturması gerektiği üzerinde durularak, burada ele alınmıştır. 1987Brundtland Raporunda bugünün ihtiyaçlarını karşılarken gelecek kuşakların gereksinimlerini göz ardı etmeden ortak bir geleceği inşa etme çabası olarak "Bizim Ortak Geleceğimiz" adlı raporu yayınlayarak sürdürülebilir kalkınmanın önemine vurgu yapılmıştır (Ballı,2019: 467 ). Belirli tarihlerde sık sık gündeme gelen sürdürülebilirlik kavramı yaşamın pek çok alanında yer edinmiştir. Sürdürülebilirlik "Sürdürülebilir Kalkınma" kavramı ile ortaya çıksa da günümüzde "Sürdürülebilir Yaşam, 'Sürdürülebilir Sağlık Hizmetleri, 'Sürdürülebilir Eğitim, 'Sürdürülebilir Tasarım', 'Sürdürülebilir Tarihi Yapı' ve 'Sürdürülebilir Mimari' gibi birçok alanda kullanılmaktadır.

\subsection{Sürdürülebilir Mimari ve Hedefleri}

Pek çok alanda ortaya atılan sürdürülebilirlik kavramı mimari alanında da "Sürdürülebilir Mimari" olarak ortaya çıkmaktadır. Sev (2009: 18) eserinde, sürdürülebilir mimarlığı "içinde bulunduğu koşullarda ve varlığının her döneminde, gelecek nesilleri de dikkate alarak, yenilenebilir enerji kaynaklarının kullanımına öncelik veren, çevreye duyarlı, enerjiyi, suyu, malzemeyi ve bulunduğu alanı etkin şekilde kullanan, insanların sağlık ve konforunu koruyan yapılar ortaya koyma faaliyetlerinin tümü" olarak tanımlamıştır. Sürdürülebilir mimarinin hedefi yapıların sonraki nesillere bozulmadan aktarılabilmesinin yanı sıra mimari yapının tasarım ve uygulama sürecinde harcanan enerji, doğaya salınan karbon miktarı, kullanılan malzemenin doğa ile uyumu, sadece varlığı süresince değil; ömrünü tamamladıktan sonra da çevreye ve insan sağlığına etkisi gibi pek çok unsur da göz önünde bulundurularak tasarım yapmaktır. Sürdürülebilir mimari kavramı 1970'lerde "çevresel tasarım", 1980'lerde "yeşil tasarım", 1980'lerin sonu ve 1990'larda "ekolojik tasarım", 1990’ların ortasından günümüze "sürdürülebilir tasarım" terimi ile ele alınmıştır. Terminolojideki değişim, bu konuda genişleyen mimari teori ve uygulama alanına işaret eder. Sürdürülebilir mimari, önceki mimari yaklaşımları da kapsayan bir üst başlık olup, küresel çevre sorunları ve gelişme 
problemlerine çözüm olarak desteklenen, bütüncül, stratejik ve planlı bir yapılaşma şeklidir. Böylece morfolojik özellikleriyle olduğu kadar, yörenin toplumsal, kültürel ve ekonomik altyapısına yaptığı katkıyla da çevreye duyarlı sayılan bir mimari pratik öngörülmektedir (Arsan, 2008: 21).

\section{Tarihi Yapı}

Tarihi çevrenin bileşenlerinden olan tarihi yapılar; kentlerin kimliğinin oluşumunda en önemli unsurlar olarak kabul edilmektedir (Zeren, 2019: 22). Tarihi yapı; farklı kültürlere ve uygarlıklara ev sahipliği yapmış, bir toplumun kültür birikimiyle şekillenen ve geçmiş ile gelecek arasında köprü görevi gören geleneksel, görsel değerler taşıyan, geçmişten bizlere miras olarak kalmış, döneminde yaşamış insan topluluklarının kalıntılarının bulunduğu, geçmiş dönemlerde yaşamış insanlardan kalan yapılardır (Değirmenci ve Sarıbıyık, 2015: 2-3). Tarihi yapılardan elde edilen verilerle toplumların kendilerine has özelliklerini, geçmiş yaşamlarını, yaşayış biçimlerini, kültürel ve sosyal hayatlarını, inanışlarını, ilgili dönemin dokusunu, siyasi, kültürel ve ekonomik durumunu anlayabilmek mümkün olduğu için tarihi yapılar öncelikli korunması gereken önemli eserlerdir.

\subsection{Sürdürülebilirlik Açısından Tarihi Yapıların Korunması ve Restorasyonu}

Birer kültürel miras olan tarihi yapılar yalnızca bünyesinde barındırdığı milletlerin tarihine değil; dünya tarihine kalan birer mirastır. Fakat dünya üzerinde büyük bir hızla artan nüfus ile beraberinde getirdiği çarpık kentleşme içerisinde tarihi yapıların varlığını sürdürmesinde oldukça büyük sorunlarla karşılaşılmaktadır. Karşılaşılan sorunların çözülebilmesinde bütünleşik bir koruma anlayışının geliştirilmesi gerekmektedir. Bu anlayış, Avrupa Konseyi'nin 1975 yılını Dünya Mimari Miras Yılı ilan etmesi ardından yayınlanan Amsterdam bildirgesiyle ortaya konulmuştur. Bu bildirgede sosyal dokunun korunması, yapı için uygun işlevin belirlenmesi, hassas restorasyon tekniklerinin uygulanması ve tarihi yapının fiziksel çevresi içinde yaşayanların korunmasına özen gösterilmesinin gerekliliği üzerinde durulmuştur. Bu düşünceden yola çıkarak bütünleşik bir koruma anlayışı kapsamında, tarihi yapıları yeniden işlevlendirmek dünyanın pek çok ülkesinde güçlü bir alternatif haline gelmiştir (Tanrısever, 2016: 1069). Birer dünya mirası olan, geçmişin izlerini taşıyan bu tarihi yapıların sürdürülebilirliğini sağlamak için koruma, sağlamlaştırma, restorasyon ve yeniden işlevlendirme uygulamalarının bütünleşik koruma anlayışı sonucu oluşan yenileme çalışması kapsamında oldukça büyük bir dikkatle gerçekleştirilmesi gerekmektedir. Yapılan yenileme çalışmalarının tarihi yapının yaşatılabilmesi için doğru bir işlev ile yeniden işlevlendirilmesi, özgün mimari stil ve mekân özelliklerini koruması, doğru malzeme seçimi ve uygulama yöntemlerinin kullanımı, mekânı oluşturan ögelerin ve donatı elemanlarının yeniden işlevlendirmede özgün halinin korunması, sonradan mekâna ilave edilen öge ve donatı elemanlarının işlev sona erdiğinde kaldırılabilmesi, böylelikle mekânın özgün halinin geri kazanımının sağlanması gerekmektedir. Bu önemli çalışmalar gerektiği şekilde yapılmadığında vahim sonuçlar doğurması kaçınılmaz olacaktır (Zeren, 2012: 25). Bu vahim sonuçlara Türkiye'den; Şekil.1'de görülen Marmara Üniversitesi Göztepe Yerleşkesinde bulunan Av Çiftliği'ndeki hamamın 2016 yllında geçirmiş olduğu restorasyon çalışması, Şekil.2'de görülen İstanbul'un Şile ilçesinde 2000 yıllık Cenevizlilerin inşa ettiği tarihi “Ocaklı Ada Kalesi”nin restorasyon çalışması, Şekil.3’te görülen Türkiye'nin Sümela Manastırı'ndan 
sonraki ikinci büyük manastırı olan Giresun “Meryem Ana Manastııı”nın restorasyon çalışmaları, Şekil.4'te görülen Gaziantep'in Araban ilçesinde bulunan 19 asır önce inşa edilmiş antik Roma döneminden kalan Septimius Severus Köprüsü'nün restorasyon çalışması ve Şekil.5’te görülen Sivas'taki Evliya Çelebi'nin 'Benzeri bir daha asla yapılamaz' dediği, asitle yok edilen 750 yıllık tarihi eser, Gök Medrese çinilerinin restorasyon çalışmaları örnek olarak verilebilir.

Şekil.1-i̇stanbul Av Çiftliği Tarihi Hamam Restorasyonu

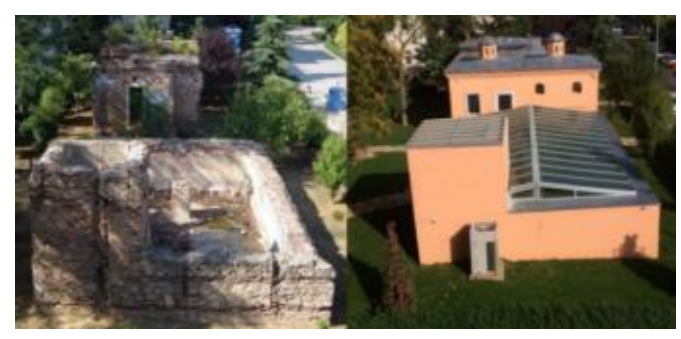

Şekil.2-Şile Ocaklı Ada Kalesi Restorasyonu

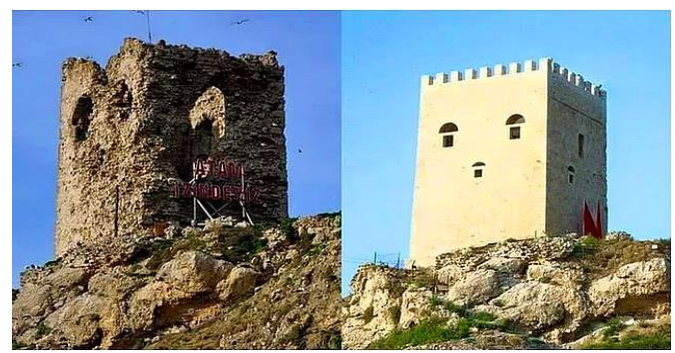

Kaynak: https://tr.sputniknews.com ,2019

Şekil.3-Giresun Meryem Ana Manastırı Restorasyonu

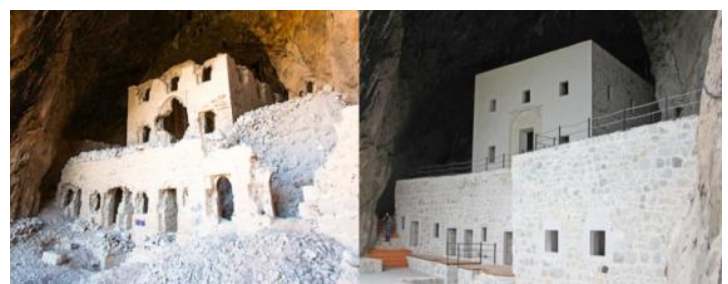




\section{Şekil.4-Gaziantep Septimius Severus Köprüsü Restorasyonu}

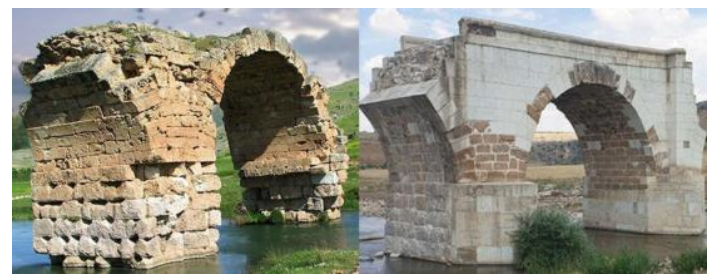

Kaynak: https://arkeofili.com,2019

Şekil.5-Sivas Gökmedrese Çinileri

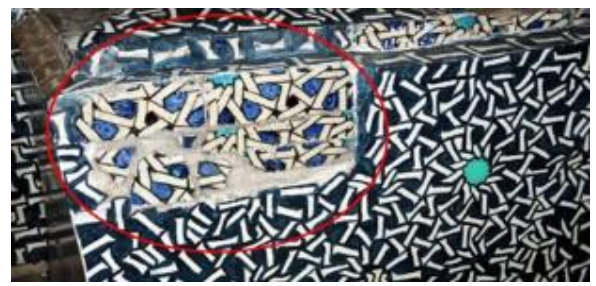

Kaynak: https://tr.sputniknews.com ,2019

Büyük öneme sahip olan tarihi yapıların korunması ve gelecek kuşaklara aktarılması, eğitim, bilgi ve sürekli bakımla mümkündür. Tarihi yapıların doğal afetler, olumsuz çevre koşulları ve fizikselkimyasal bozulmalarla mücadelesinin yanında, insanoğlunun bu yapılara karşı aldığı tavır ile tarihi yapıların yok olma sürecini hızlandırmasına karşı da bir mücadelesi vardır (Mahrebel, 2006: 12). Tarihi yapıların restorasyonu ve onarımı sırasında yapılan hataların doğurduğu kötü sonuçları engellemek için bazı sürdürülebilirlik yöntemleri gündeme gelmiştir. Elde edilen bilgiler ışığında bu sürdürülebilirlik yöntemleri şu şekilde özetlenebilir: (1) Sürdürülebilirliğin ilk adımı "koruma"dır. Tarihi yapılar içerisinde yaşam varken de yaşam sonlandığında da insanlar tarafından dikkatle kullanılmalı ve zarar verilmeden korunmalıdır. (2) Yapıları koruma bilincine ulaşmak için toplumdaki bireylere bu konuda yeterli bilgilendirmeler yapılmalı, belirli sürelerde eğitim verilmelidir. (3) İyi korunmuş olmalarına rağmen tarihi yapılarda zamanla ortaya çıkan deformasyonların restorasyonu konusunda uzman olan, işinin ehli kişiler tarafından aslına uygun bir şekilde, yapıya ve doğaya uygun malzemeler ve doğru uygulama teknikleri seçilerek gerçekleştirilmeli, her adımı belgelenerek kaydedilmelidir. (4) Tarihi yapıların içinde bulunduğu dönemin ihtiyaçlarına yönelik olarak yeniden işlevlendirilmesi süreci, yapının özgün projesinde değişiklik yapılmadan gerçekleştirilmelidir. Tarihi yapının dönemin gereği olarak yüklenen fonksiyonu ortadan kaldııldı̆̆ında da yapının aynı değeri koruması sağlanmalıdır. Tüm bu unsurlara dikkat edildiği takdirde tarihi yapıların tarihi kimliğini kaybetmeden, uzun süre yaşatılmaları, sürdürülebilir yapı kimliği kazanmaları mümkün olabilecektir. 


\section{Sürdürülebilirlik Açısından Eskişehir Odunpazarı Evleri}

Eski çağda Dorylaion olarak bilinen Eskişehir 1176'da II.Kılıçarslan'ın Bizanslıları mağlup etmesinden uzun bir süre sonra yeniden kurulmuştur. Osmanlı topraklarına çok erken katılan Eskişehir,14.yüzyıldan itibaren Sultan Önü olarak anılmaya başlanmıştır. Bu şehrin ilk yerleşim yeri Eskişehir'in Güney tepelerine konumlanan Odunpazarı'dır. Bu bölge kentsel gelişmesini Cunudiye, Şarkiye, Akarbaşı, Akcami, Akçağlan, Dede, Karapınar, Paşa ve Ortamahallelerden bazılarının tümünü, bazılarının da bir kısmını içine alacak şekilde sürdürmektedir (Nalçakan, 1993: 117). Eskişehir tarihi için oldukça büyük bir öneme sahip olan şehrin ilk yerleşim yeri Odunpazarı bölgesi tarihsel süreçte yaşadığı pek çok olaya rağmen betonlaştııımamış ve geleneksel dokusunu korumuştur (Karasözen ve Koca, 2012: 4). Bunun en önemli sebebi şehrin gözde merkezlerinden biri iken bir dönem terkedilerek yalnız bırakılmış tarihi evlerin yıkılmamış ve kendi haline bırakılmış olmasıdır. Kendi haline bırakılmış tarihi Odunpazarı Evleri zaman içerisinde yıkılmaya yüz tutunca 2000'li yıllardan itibaren Odunpazarı Belediyesi tarafından gerçekleştirilen restorasyon çalışmaları ve sosyo-kültürel alt yapının geliştirilmesi çalışmaları ile hayata kazandırılmış ve günümüzde de tarihini yaşatmaya devam etmekte olup; Eskişehir'e yeni bir turistik kent imgesi kazandırmıştır (Öztürk, 2016: 865). Bu çalışmada sürdürülebilirlik yöntemleri dikkate alınarak Odunpazarı semtindeki, Osmanlı Dönemi'nden kalma tarihi evleri bünyesinde barındıran, tarihi Odunpazarı Evleri'nin sürdürülebilirlik açısından değerlendirmesi yapılmıştır. Odunpazarı evleri bu bağlamda daha önce de birçok araştırmacının çalışma konusu olmuştur. Prof. Dr. Yelda Uçkan ve Erkan Uçkan'ın 2006 yılında yayımlanan “Odunpazarı Evleri” adlı kitabı, Prof.Dr. Neslihan Sönmez'in 1983 yılındaki "Eskişehir'de Odunpazarı Tarihi Yerleşiminin Fiziksel Gelişimi ve Geleneksel Konut Dokusunda Dizgesel Çözümlemeler" adlı doktora tezi, Şerife Özüdoğru, Dr.Öğr.Üyesi Zeynep Ertuğrul ve Öğr.Gör.Dr. Selma Manaz'ın "Eskişehir Odunpazarı ve Sivrihisar Evlerinin Cephe Örnekleri” adlı makale çalışması, Prof.Dr. Ayşen Çelen Öztürk'ün “ Eskişehir'in Geçmişteki ve Bugünkü Kent Belleğinin Zihin Haritaları Üzerinden Okuma Denemeleri” adlı makale çalışması ve Prof.Dr. Meral Nalçakan'ın 1993 tarihli "Tarihi ve Kültürel Sürekliliğin Fiziksel Çevrede Değişime Yansıması ve Eskişehir Örneği" adlı doktora tezi, Odunpazarı Evleri konusunda yapılmış önemli akademik çalışmalardan bazılarıdır. Pek çok akademik çalışmaya konu olan tarihi Odunpazarı semti Gayrimenkul Eski Eserler ve Anıtlar Yüksek Kurulu tarafından 1981 yılında 2808 sayılı kararla tarihi ve kentsel sit olarak belirlenmiştir. 1986 yılında ise Kültür ve Tabiat Varlıkları Yüksek Kurulu’nun 2397 sayılı kararıyla Kentsel Sit niteliği kazanmıştır (Uçkan ve Uçkan, 2002: 27).

\subsection{Odunpazarı Yerleşimi}

Tarihi Odunpazarı Evleri'nin bulunduğu, şehrin en eski yerleşim bölgesi olan Odunpazarı bölgesi şehrin kuzey tepelerine kurulmuştur. Eskişehir'in tam ortasından geçen Porsuk Çayı kenti yukarı ve aşağı olarak ikiye ayırmıştır. Porsuk'un alt kısmında kalan kısım “sıcak sular” çarşı bölgesini kapsarken üst kısmında kalan "yukarı şehir" Odunpazarı bölgesini kapsamaktadır. Odunpazarı 19. yüzyıla ait geleneksel Türk Evleri dokusunu ve bulundukları dönemin sosyo kültürel özelliklerini ortaya koyan, 
Kurşunlu Külliyesi etrafında kurulan bir semttir ve oldukça ilginç bir kuruluş söylencesi vardır: "Kente ilk yerleşmeye gelenler, üç koyun ciğerini birer sırı̆ın üzerine yerleştirerek, bu sırıkları, bugün bilinen isimleriyle Şarhöyük, Porsuk kenarı ve Kurşunlu Camiinin olduğunu yerlere dikerler. Şarhöyük ve Porsuk kenarına konulan ciğerler hemen bozulur. Kurşunlu Camii'nin yakınına yerleştirilen ciğerlerse bozulmadan kalır. Böylece en temiz havanın burada olduğuna karar verilerek, buraya yerleşilir." (Bir Söylence ve Odunpazarı, 2006: 12). Odunpazarı yerleşimi Selçuklu Sultanı II. Kılıçaslan'ın 1176'da Karacaşehir Kalesi'ne yerleşmesinin ardından kalenin doğusundaki Şarkiye Mahallesine yerleşmesi ile oluşmuştur. Bu yüzden Şarkiye Mahallesi Odunpazarı bölgesinin ilk mahallesi olarak bilinmektedir. Bölgede köylüler odun sattığı için bölge Odunpazarı adını almıştır. Osmanlı öneminde ise "Karacaşehir" olarak bilinen Odunpazarı bölgesinin günümüzde 85 mahalleden oluştuğu bilinmektedir.

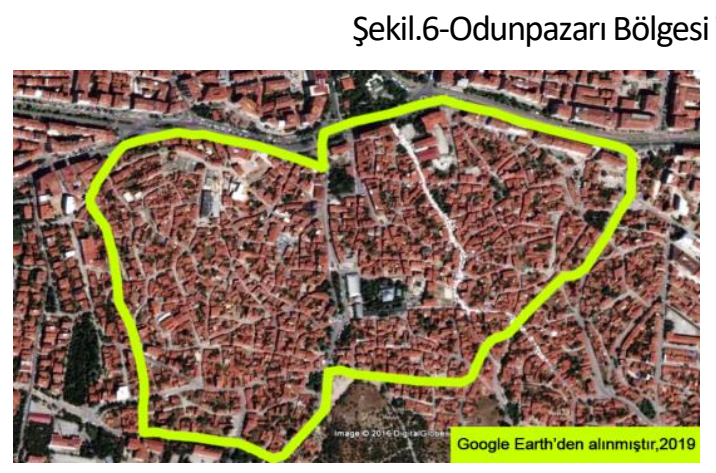

Kaynak: Google Earth'den alınmıştır.

Şekil.7-1923'te Odunpazarı , Şekil.8-1930'larda Odunpazarı, Şekil.9-1960'larda Odunpazarı

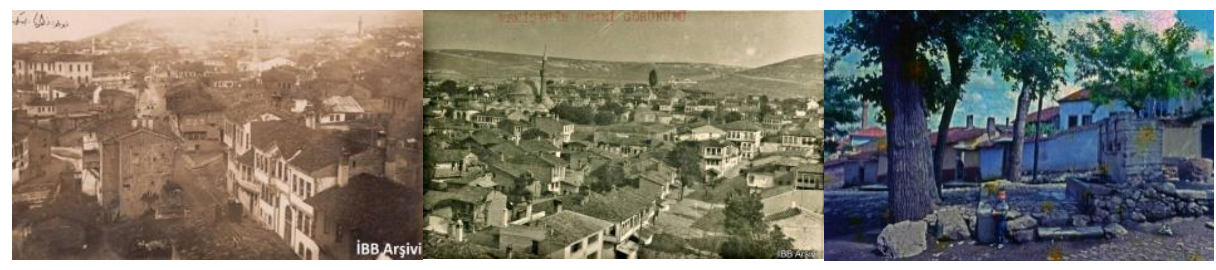

\subsection{Odunpazarı Evlerinin Genel Mimari Özellikleri}

Çoğunluğunun 18.yy. ve 19.yy. arasında yapıldığı bilinen Odunpazarı Evleri ilk olarak dar ve kıvrımlı sokakları, bitişik nizam rengarenk cumbalı tarihi ahşap evleri ve evlerin iç içe olmasına rağmen mahrem sınırlarını aşmadan birbirine sayg duyduğu yerleşim planı ve evleriyle dikkat çekmektedir. Birbiriyle yarışmayan, son derece mütevazı tasarlanmış tarihi Odunpazarı Evleri, dökülmüş sıvaları arasından da görüldüğü üzere, ahşap karkas arası kerpiç dolgu gibi geleneksel Türk konutu yapım teknikleri ile inşa edilmiştir ve geleneksel Türk konutunun temel özellikleri de görülmektedir: "Kimse kimsenin içine bakmıyor, kimse kimsenin havasını, güneşini, göz hakkını, bakışını kesmiyor. Kimse kimseyi kirletmiyor (Bektaş, 2013: 34)." 
Şekil.10-Günümüzde Odunpazarı

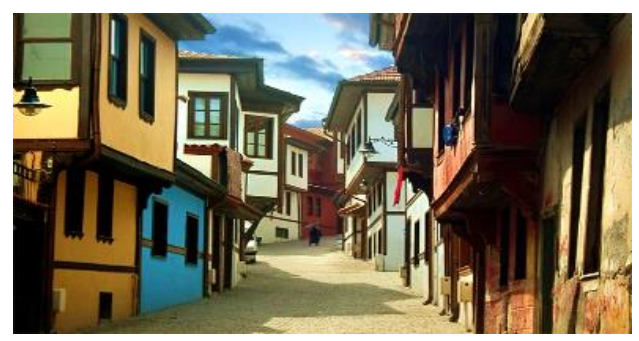

Kaynak: http://sinemakultur.com, 2019

Odunpazarı Evleri'nin sokak dokusu tipik geleneksel Anadolu-Türk kenti modelindedir. Sokakları arazinin eğimine uygun olarak düz ya da eğilen kıvrılan bir yapılaşma gösterirler. Bünyesinde birçok tarihi olaya tanıklık etmişönemli yapıları barındıran bu tarihi evler geleneksel Türk şehirlerine ait özellikleriyle Eskişehir'in dokusundan ayrı bir doku oluşturmaktadır. Bu doku bitişik nizamlı konutların yanı sıra, yer yer hafif eğimli kaldırım taşlarının oluşturduğu, dar ve dolambaçlı sokaklar şeklindedir. Bitişik nizam, 100-150 m² parsel büyüklüğü ve komşu binaların konumlanmaları yerleşim düzenini etkilemiştir (Atıcı, 2017: 7-9). Evler çoğunlukla sokağa açılır ve büyük bölümünde sokaktan algılanamayan bir arka bahçe bulunmaktadır. Genellikle iki katlı olan evlerin alt katları kiler, depo, kömürlük, ambar olarak kullanılır ve cephelerde küçük pencereler bulunur. Orta ve üst katlarda ise sokağa taşan çıkmalarla dış dünyayla iletişim sağlanmıştır. İki veya daha çok katı evlerde üst katlar yeme, yatma, dinlenme, oturma ve konukları ağılama amacına yönelik bir mekân düzenlemesinden oluşur. Ev çıkma sayesinde kendini sokağa bağlayan bir yaşam biçimine sahip olur. Giriş çoğu zaman avludan gerçekleşmektedir (Özüdoğru vd., 2005: 18-19). Odunpazarı Evleri'nin pencereleri genellikle giyotin, kapıları ise çift kanatlı veya tek kanatlıdır. Pencere boyutları mevsimsel olarak hangi kat kullanılıyorsa ona göre değişmektedir. Kapıların değişiklik göstermesinin sebebi ise ailenin gelir durumuyla ilişkilidir. Şayet ev sahibinin gelir durumu fazlaysa ve bir at arabası varsa, at arabasının bahçeye kolaylıkla girebilmesi için bahçede çift kanatlı kapı görülürken, at arabası olmayan ailelerin evinde tek kanatlı kapı görülmektedir. Hımış yapım tekniğindeki Odunpazarı evlerinde genellikle temel duvarları moloz taş, taşıyıcı duvarlar yığma kerpiç veya daha çok ahşap iskelet arası kerpiç ya da tuğla dolgu; bölme duvarları ise ahşap karkas arası kerpiç ya da tuğla dolgu veya dolgusuz, iki tarafı ahşap kaplamalı olarak inşa edilmiştir. Duvarların iki yüzü de sıvalıdır. Moloz taşla örülen temel duvarlarında bağlayıcı olarak saman karıştırılmış çamur harç kullanılmıştır. Bölgede en çok görülen teknik, ahşap karkas arasının kerpiç veya tuğla ile doldurulmasıdır. İskelet sistemi dikmelerin payandalarla desteklenmesi ve pencerelerin alt ve üstlerinden birbirine bağlanması ile oluşturulmuştur. Çatkı arasındaki kerpiç ya da tuğla dolgunun derzleri çamur veya kireç katkılı harçla birleştirilmiş, yüzeyleri bağdadi tekniğinde sıvanmıştır. Döşemeler zemin katta taş, toprak veya ahşap, üst katlarda ise tümüyle ahşaptır. Odaların tümünde sıvalı ya da ahşap tavanlar yapılarak döşeme kirişlerinin altı kapatılmış, sirkülasyon alanlarında ise tavan kirişlemesi genellikle açık bırakılmıştır (Eskişehir Odunpazarı Kentsel Sit Alanı Koruma Amaçlı Imar Planı Revizyonu, 2011: 52). Bahsedilen yapım teknikleri Şekil.11 'de, ahşap oda tavanları ve döşemeler de Şekil.12' de açıkça 
görülmektedir. Genelde ev sahibinin maddi durumuyla paralel olarak tavanlar bazı evlerde son derece zengin bazılarında ise sade dekorasyona sahiptir. Bu odalarda ocak, dolap, yüklük, gusülhane, lambalık gibi unsurlar da yer alır (Uçkan ve Uçkan, 2002: 64-65).

\section{Şekil.14-Odunpazarı Evleri Yapım Tekniği Detayları}

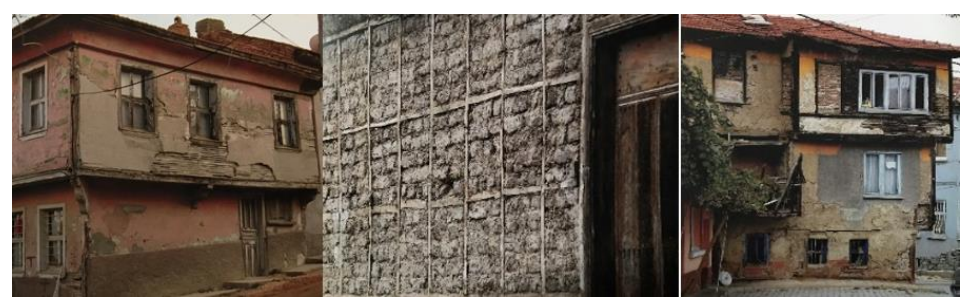

Kaynak: Uçkan vd,2002,s.57-77

Şekil.15-Odunpazarı Evleri İç Mekân

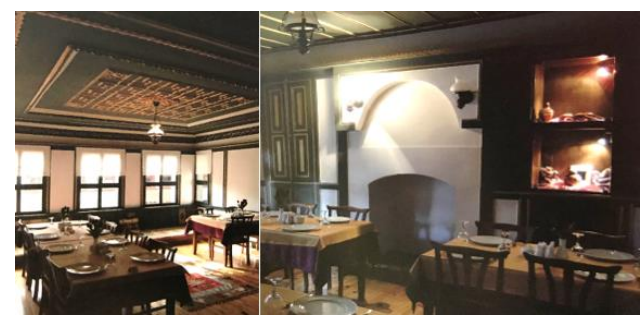

Kaynak: Uçkan vd,2002, s.64-65

Bahçelerinden yeşilin taştığı avlulu yerleşim planına sahip, genellikle iki katlı olan evlerin süslemeli ahşap iç mekân detayları yanı sıra evlerin yaşayış biçimleri ile de geleneksel Türk mimarisinin önemli örnekleri arasında olduğu görülmektedir. Odunpazarı Evleri bünyesinde tarihi ve mimari açıdan oldukça önemli olan pek çok konak barındırmaktadır. Bu konaklara 6.yüzyıldan kalma Osmanlı dönemine ait Kurşunlu Camii ve Külliyesi dışında Atatürk'ün misafir edildiği Yeşil Efendi Konağı (Osmanlı Evi) , Hafız Ahmet Efendi Konağı, Dalyancı Konağı ve Yağcızade Konağı gibi konaklar örnek verilebilir. Kurşunlu külliyesi Eskişehir'in Odunpazarı semtinde bulunmaktadır. Külliye, içerisinde yer alan caminin kubbesinin kurşunla kaplı olmasından kaynaklı birçok şehirdeki benzer yapılar gibi "Kurşunlu" ismiyle anılmaktadır. Kitabesine göre, 1500lü yıllarda Kanuni Sultan Süleyman'ın vezirlerinden Çoban Mustafa Paşa tarafından yaptırılmıştır. Külliyenin merkezinde cami yer alır. Caminin doğusunda; matbah, batısında; imaret, kuzeybatısında; büyük kervansaray, güneybatısında; küçük kervansaray ile düşkünler evi, güneydoğusunda; zaviye, kuzeyinde; şadırvan, kuzeydoğusunda ise yeni yapılar olan; kalorifer dairesi ve yer altında tuvaleti bulunmaktadır. Külliyede; doğu, batı, kuzey, güney yönünde dört giriş bulunmaktadır. Ana giriş kapısı eskiden kuzeyde, şadırvana açılan kapı iken, günümüzde ana giriş kapısını batıdaki küçük kervansaray ile aşevi arasındaki kapı oluşturmaktadır (Altınsapan ve Tulum, 2016: 2). Odunpazarı́ndaki bir diğer önemli yapı da tek çatı altında çift çıkma ile yapılan Yeşil Efendi Konağıdır (Şekil.12). Yeşil Efendi 
Konağı, 19. yüzyıla ait ahşap mimarinin önemli örnekleri arasında yer alır. Kurtuluş Savaşı sırasında Mustafa Kemal Atatürk'ün burada misafir kalması nedeniyle konak ayrı bir önem taşır (Yüksel vd., 2015: 155). İç mekândaki ahşap tavanları, çıtakari ve kündekari süslemeleri ile dikkat çeken Odunpazarı́ndaki en süslü konaklardan biridir. Restorasyon çalışmalarından sonra Osmanlı Evi, müze ve restoran olarak hizmet vermeye başlamıştır. Önemli bir diğer konak ise lületaşı ustası Hafız Ahmet Efendi tarafından 1717 yılında yaptırılan Hafız Ahmet Efendi Konağıdır (Şekil.12). Bu konakta da yine yapım tekniği olarak geleneksek Türk konutu tekniklerinden ahşap karkas arası kerpiç dolgu tekniği görülmektedir. Geniş bir avluya sahip olan konak restorasyon çalışmalarından sonra kafeterya olarak çalışmaya başlamıştır.

Şekil.11 -Kurşunlu Camii ve Külliyesi

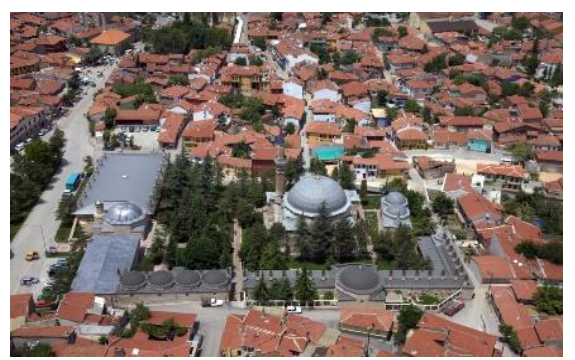

Şekil.12- Yeşil Efendi Konağı (Osmanlı Evi)

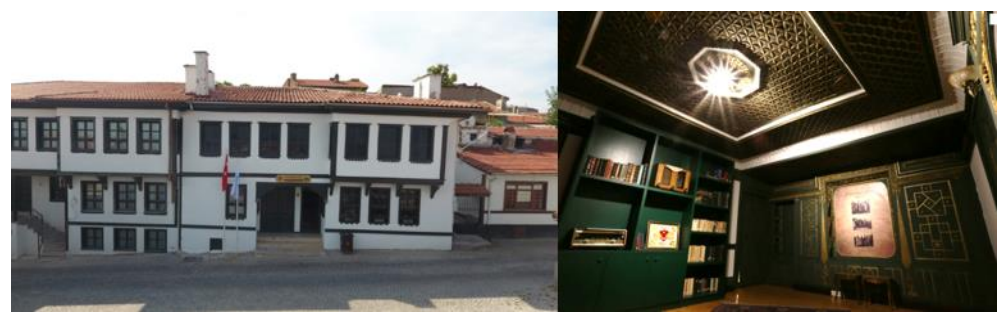

Şekil.13- Hafız Ahmet Efendi Konağı

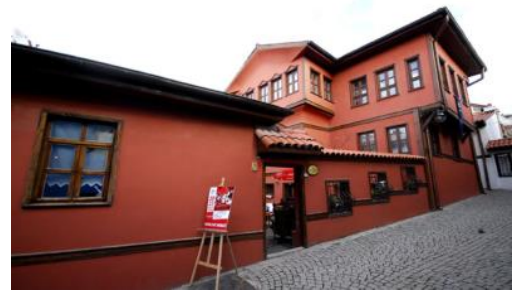

Kaynak: http://www.mustafacambaz.com ,2020 
Ülkemizin dünya kültür mirasına eklenen, Eskişehir'in en eski yerleşim yeri olan bu tarihi evler Odunpazarı Belediyesi tarafından restore edilmiştir. Odunpazarı evleri günümüzde halen konut, atölye, müze, kafeterya ve benzeri işlevlerle kullanılmaktadır.

\subsection{Odunpazarı Sit Alanı Kapsamındaki Restorasyon Çalışmaları}

1973'den itibaren koruma altında olan Odunpazarı Bölgesinde 2005 yılında "Odunpazarı Evlerini Yaşatma Projesi" kapsamında restorasyon çalışmaları başlatılmıştır. Projeye Kültür Bakanlığı, Anadolu Üniversitesi Mimarlık Bölümü, Vakıflar Genel Müdürlüğü ve diğer sivil toplum kuruluşları destek vermiştir. Restorasyon ile beraber hayalet bölge olan Odunpazarı bölgesi, sokak iyileştirme çalışmalarıyla bölgenin alt yapısı iyileştirilmiş, terkedilen yapılara kafeterya, restoran, otel gibi işlevler kazandırılarak yeniden canlandııımış ve böylece bölge turizme açılmıştır. Kültür ve Turizm Bakanlığı tarafından 1'inci Ulusal Mimarlık Koruma Ödülü'nü kazanan, UNESCO Dünya Miras Geçici Listesi'nde yer alan ve bu proje kapsamında 30 sokakta 300 ev, 3 Camii, 1 Külliye, 2 Kervansaray, 15 Çeşme, 1 Han'ın restorasyonu gerçekleştirilmiştir. Bölge halkı ve Eskişehir Büyükşehir belediyesi ve Odunpazarı belediye iş birliği ile bölgede dokuyu korumak, çöküntü bölgesini kurtarmak, turizmi canlandırmak ve ticareti geliştirmek hedeflenmiştir (https://eskisehir.ktb.gov.tr, 2020). Odunpazarı bölgesi restorasyon çalışmalarının "Odunpazarı Evlerini Yaşatma Projesi" adını almasının sebebi Odunpazarı Evlerinin yıllar içerisinde pek çok zorlu süreçten geçmesi ve bu süreçler sonunda evlerin ve bölgenin zarar görmüş, terk edilmiş, ölü bir bölge haline gelmesidir.

\subsubsection{Sosyokültürel ve Ekonomik Süreç}

Odunpazarı Belediyesi yetkilileri ile yapılan görüşmeler sonucu Odunpazarı Evlerinin sosyokültürel ve ekonomik süreci hakkında elde edilen veriler şöyledir: "Odunpazarı kentsel yerleşimin ilk kurulduğu bölge olup yerli halkın ikametinden dolayı sivil mimarî ağırlıkı bir semttir.1854'ten itibaren Kırım ve Balkanlar'dan gelen göçlerle kentin ve Odunpazarı́nın sosyokültürel yapısı hareketlenmiş, 19. yüzyıl başlarında demiryolunun da gelmesiyle halkın maddî gücü belirgin bir artış göstermiştir. Tarım ürünleri ve hammadde temini kolaylaşmış ve bu artış, azınlık grupların da kente ilgisini arttırmıştır. Artan maddî imkânlar ile Odunpazarı Evleri'nin tipolojisinde de çeşitli değişiklikler gözlemlenmiştir. Taşra kentlerine özgü eşraf konakları yapılmış, ayrıca "cihannüma” gibi bölümlerin görülmesi de ev halkının beğeni ve zevklerindeki artışın göstergesi olmuştur. Ev sahiplerinin faytonlarından inmeksizin bahçelerine girebilecekleri boyutlarda bahçe kapıları görülmüş, bahçe duvarları da bahçenin, sokaktan geçen bir devenin üstündeki insan tarafından görülemeyeceği kadar yükselmiştir.20. yy. başlarına kadar kentin elit ve seçkin kesiminin ikamet ettiği bölge işgal yıllarında büyük bir fiziksel ve sosyal yıkım yaşamıştır. İşgalden kaçanlar evlerini terk etmiş ve bu evlerin çoğu işgal sırasında düşman askerleri tarafından kullanıımış, talan ve tahrip edilmiştir. Belli bir süre sonra yaralar sarıldıkça, bu bölgedeki mülklerin sahipleri de konaklarına dönmeye başlamışlardır. Atılım yılları ile birlikte tüm Türkiye gibi Eskişehir de gelişmeye başlamıştır. Bu gelişim ile kent Porsuk boyunca büyüme göstermiştir. Dolayısıyla Odunpazarı eski günlerindeki ününü yitirmiştir. Sürekli olarak sosyal yaşantının odağında yaşamaya alışkın aileler konaklarını terk ederek, "aşağı mahalle"lerde yeni inşa edilen binalara yerleşmişlerdir. Elit ve zengin 
aileler bölgeyi terk ettikçe, boşalan konaklara nispeten daha alt sosyo-kültürel ve ekonomik seviyeden kiracılar yerleşmeye başlamıştır. Evler ve sokaklar giderek bakımsızlaşmış ve dejenere olmuştur. Yaşanan bu gelişmelerle birlikte Eskişehir'in merkezi Odunpazarı bölgesi olmaktan çıkmıştır. 1950'lerle birlikte patlama yaşayan müteahhitlik ile kentin konut stoğu artmış ve yıllar önce sahiplerinin terk ettiği Odunpazarı'nı bu sefer de kiracıları terk etmeye başlamıştır. Bu durum, bölgeye sosyo-kültürel ve ekonomik açıdan büyük bir darbe indirmiş ve bölge unutuldukça, temel şehircilik hizmetleri de aksamaya başlamıştır. Bir çöküntü bölgesi haline gelen Odunpazarı'nda konakların fonksiyonlarındaki değişim ile paralel olarak mimarî özellikler de bozulmuştur. Tüm bu olumsuzluklara rağmen kent merkezindeki betonlaşma tarihi bölgeyi etkilememiş, birkaç uygulama dışında bölge tamamen korunmuştur. 1981 yılında Kentsel sit niteliği kazanması, Odunpazarı Bölgesi'nin sosyo-kültürel ve ekonomik olarak gelişmesine bir katkıda bulunmazken yalnızca korunmasının önü açılmış ve ülkemizin dünya kültür mirasına eklenen önemli eserleri arasında yer alan Eskişehir'in en eski yerleşim yeri olan bu tarihi evler belediye tarafından restore edilerek yeniden canlandırılmıştır (Odunpazarı Belediyesi, Röportaj, Aralık 2019)."

\subsubsection{Restorasyon Süreci}

Odunpazarı Belediyesi tarafından Odunpazarı Evleri'ni yaşatmak amacıyla 2005 tarihinde restorasyon sürecine başlanmıştır. Bu süreçte aktif olarak görev almış olan Odunpazarı Belediyesi yetkilileri ile yapılan birebir görüşmede restorasyon süreci şöyle anlatılmıştır: "Odunpazarı sit alanı restorasyonunun ilk aşamasında yapıları kamulaştırmak gerekmektedir. Kamulaştırma işleminden sonra yapıların var olan rölöveleri alınmakta ve rölöve, restitüsyon projeleri çizilmektedir. Rölöve bugünkü haliyle alınmakta ve restorasyon çalışmaları da bugünkü kullanım amacına yönelik olarak çizilmektedir. Restorasyon projesi ilk halinden kopmadan, planlar üzerinde herhangi bir değişiklik yapılmadan hazırlanmaktadır. Dönüştürülebilir olması kaydıyla çizilen rölöve projesinden sonra önerilen restorasyon projesinde yapı var olan fonksiyonunu yitirdiğinde eskiye döndürülmesi kaydı güdüldügü için rölövesi oldukça büyük bir dikkatle incelenmektedir. Hazırlanan projeler ayda bir kez toplanan Koruma Bölge Kurulu'na onaya sunulduktan sonra restitüsyon kaynakları istenmekte, özgün halinin nasıl olduğu incelenmektedir. Projelerdeki en önemli madde özgün izlere sadık kalınarak, yapının ilk haline döndürülmesidir. Bu madde 2863 sayılı kanuna tabidir. Restorasyon sırasında değişiklik yapılırsa tadilat projesiyle koruma kuruluna onaya sunulur ve ancak onaylanırsa eylem gerçekleştirilir. Restorasyon süreci elbette ki büyük bir dikkat ve zaman isteyen bir iştir. Uygulama sırasında mekâna ölçüm için insan ve makine girdiğinden, Ocak, Şubat ve Aralık aylarında çalışılmadığı varsayılırsa, ortalama 10 -12 aylık süreçte, 3 aşamalı proje (rölöve, restitüsyon ve restorasyon projesi) tamamlanmış ve onaylanmış olmakta, bahar ayında uygulamasına geçilmektedir. Restorasyon için önemli bir bütçe gereklidir ve belediye kendi bütçesiyle milyonlar harcayamamaktadır. Öncelikle diğer kurumlarla yazışarak destek almaya çalışıır, valiliğin ayırdığı 'Korunması Gereken Kültür Varlıkları'na dair katkı payından ayrılan bütçe haricinde varlıklı kişiler sponsor olarak destek olmaktadırlar (Odunpazarı Belediyesi, Röportaj, Aralık 2019)." Restorasyon süreci işinin ehli kişiler tarafından dikkatle yapılmış olsa da bölgede restorasyon çalışmaları sonrası 
eski atmosferin yakalanmaması, işlevlendirme ve işlevlendirme sonrası yoğun insan sirkülasyonu ile beraber yapıların zarar görmesi gibi bazı olumsuz durumların da oluştuğu tespit edilmiştir.

\subsubsection{Sokak Sağlıklaştırma Süreci}

Odunpazarı bölgesindeki yenileme ve restorasyon çalışmalarına ilk olarak sokak sağlıklaştırma süreci ile başlanmıştır. Sokak sağlıklaştırma çalışmalarının yapıldığı sokaklar ve sokaklardaki en belirgin müdahaleler Belediye yetkilileri ile yapılan görüşmelerde belirlenmiş olup; şöyledir: "ilk restorasyon çalışması 2005 yılında Beyler Sokak'ta bulunan 27 konutta başlamıştır. Daha sonra sokağın sonu Kurşunlu Camisine çıktığı için bu adı alan Kurşunlu Cami Sokakta 2008-2009 tarihleri arasında yenileme çalışmaları gerçekleştirilmiştir. Malhatun Sokakta konut restorasyonu dışında kafeterya, pastane, atölye, karikatür müzesi gibi mekân dönüşümleri sağlanmıştır. Özgün planında var olan fakat ikamet eden insanlar tarafından kapatılmıs pencereler doğru noktalardan açılmış, cephe ve taşıyıcı sistem iyileştirmesi yapılmıştır. Işıklar Sokaktaki yenileme işlemlerinde de konutların restorasyonunda özgün halinde var olan fakat ikamet eden insanlar tarafından kapatılmış pencereler, kapılar doğru noktalardan açılarak tekrar ele alınmış, cephe ve taşıyıcı sistem iyileştirmesi yapılmıştır. Gerçekleştirilen sokak iyileştirme projesinde sadece yapılar değil, sokak zemini de bu iyileştirmeye dahil edilmiş, bozulan zemin düzeltilerek parke taşı ile döşenmiştir. Bir diğer önemli yenileme projesi Dedelek Sokak ve Mumcu Sokakta gerçekleşmiştir. Dedelek Sokakta görülen konutun özgün planında üç pencereye sahip olan ancak kapatılarak teke düşürülmüş pencereler, özgün malzemesine yakın bir ahşap malzeme ile özgün açıklıklardan yeni pencerelerine kavuşturulmuştur. Mumcu sokaktaki konutun da aynı şekilde pencere açıklıkları doğru noktalardan açılarak, özgün malzemesine yakın bir ahşap malzeme ile yeniden oluşturulmuştur." Bahsedilen sokaklardaki cephe restorasyon öncesi ve restorasyon sonrası Şekil.16, Şekil.17, Şekil.18, Şekil.19, Şekil.20, Şekil.21, Şekil.22 ve Şekil.23'te görülmektedir.

Şekil.16-Beyler Sokak, Şekil.17-Kurşunlu Camii Sokak

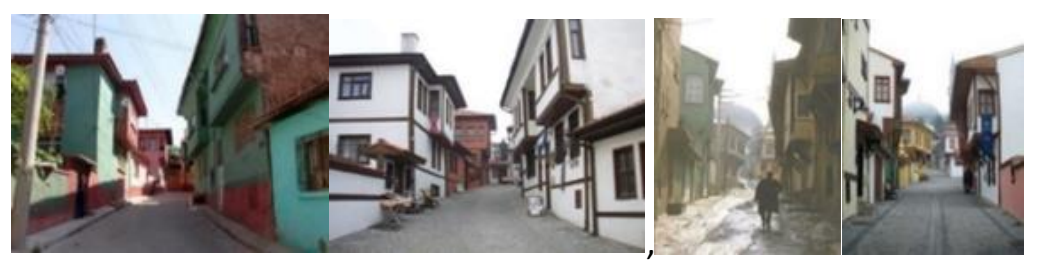

Şekil.18 -Malhatun Sokak, Şekil.19-Malhatun Sokak

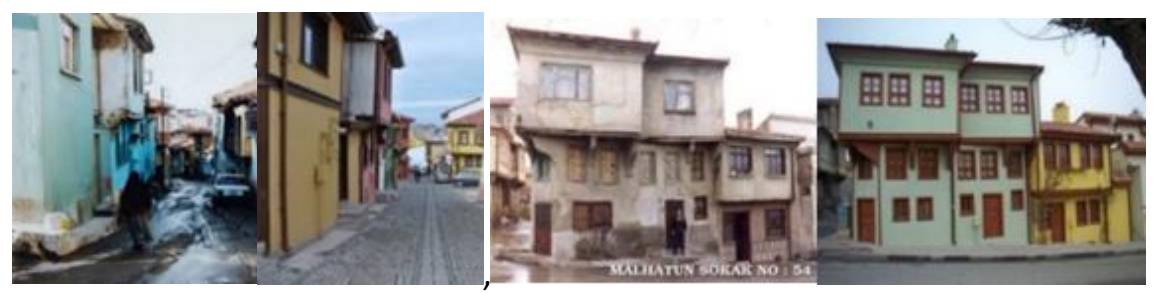


Şekil 20.Işıklar Sokak , Şekil 21. Mücellit Sokak.
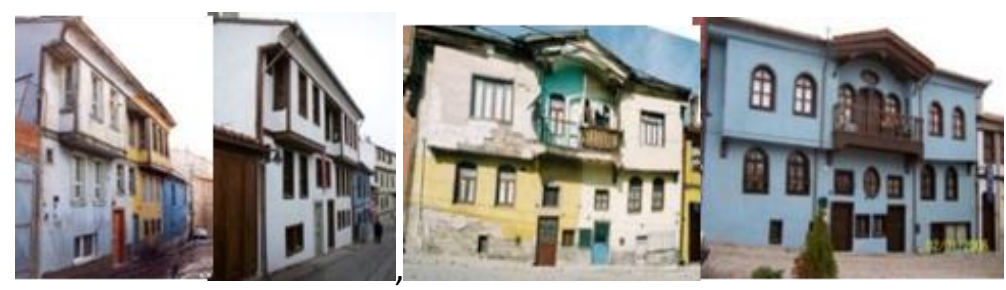

Şekil 22.Dedelek Sokak

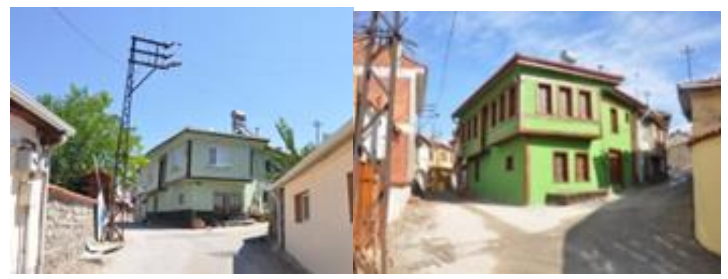

Şekil 23.Mumcu Sokak ${ }^{\ddagger}$

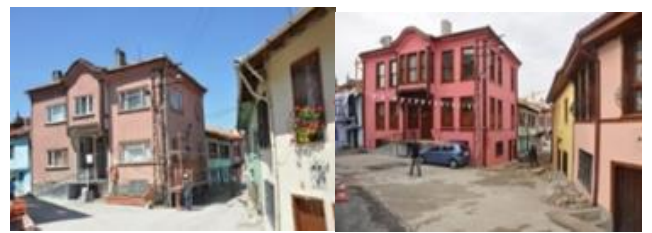

Sokak sağlıklaştırma çalışmaları ile beraber birçok konak da restorasyon çalışması geçirmiş ve bir kısmına konut dışında fonksiyonlar yüklenmiştir. Bu çalışmada ,restorasyon öncesi ve restorasyon sırası verilerine ulaşılabildiği için, Odunpazarı bünyesindeki önemli üç yapının; Yağcızade Konağı (Ataol Behramoğlu Kitaplığı), Dalyancı Konağı ve Hafız Ahmet Efendi Konağı, restorasyon çalışmaları ayrıca incelenmiştir.

\subsubsection{Yeni Fonksiyon Eklenen Konaklar}

Kurşunlu Camisi'nin olduğu sokakta bulunan önemli konaklardan biri olan Oduncular Konağı restorasyon sonucu Kırım Kültür Evi işleviyle kullanıma açılmıştır. Kültür Evi bir dönem kafeteryarestoran olarak işlev görse de günümüzde kültür evi olarak varlığını sürdürmektedir. Restore edilen bir diğer yapı ise Şekil.41'de görülen, 1790 yılında Usta Ayvaz tarafından yaptırılmış olan Usta Ayvaz Konağı'dır. Süsleme bakımından oldukça sade olan Ayvazlar Konağı semt dokusu açısından önemlidir. Restorasyon çalışmalarından sonra konak Kuzey Kafkas Kültür Evi olarak kullanılmaya başlanmışır. Eskişehir'in ilk derebeyleri tarafından yaptırıldığı bilinen yapılar restore edilerek "Bey Konakları" restorasyonunda pencere ve kapısı kapatılarak eczane olarak kullanılan alt mekân özgün

\footnotetext{
‡ Sayfadaki görseller Eskişehir Odunpazarı Belediyesi arşivinden alınmıştır.
} 
projesine uygun olarak konak bünyesine dahil edilmiş ve doğru noktalardan kapı, pencere açıklıkları geçilmiştir. Yapının yıkık durumda olan kerpiç malzemesi sökülerek dolu harman tuğlası kullanılarak onarılmış, dış cephede de horonsan harçlı sıva yapılmıştır. Yeni fonksiyon yüklenen bir diğer yapı ise 19. yy dönemine ait mimari izler taşıyan, Malhatun Sokak'ta yer alan konaktır. Konak restorasyon çalışmaları ile Balkan Kültür Evine dönüştürülmüş, günümüzde de kültür evi olarak hizmet vermektedir.

Şekil.24 - Oduncular Konağı/Kırım Kültür Evi , Şekil.25 -Usta Ayvaz Konağı/Kafkas Kültür Evi
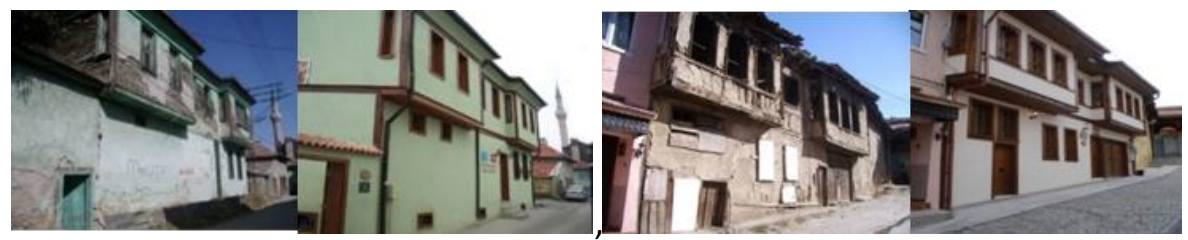

Şekil.26 Bey Konakları, Şekil.27 - Bey Konakları
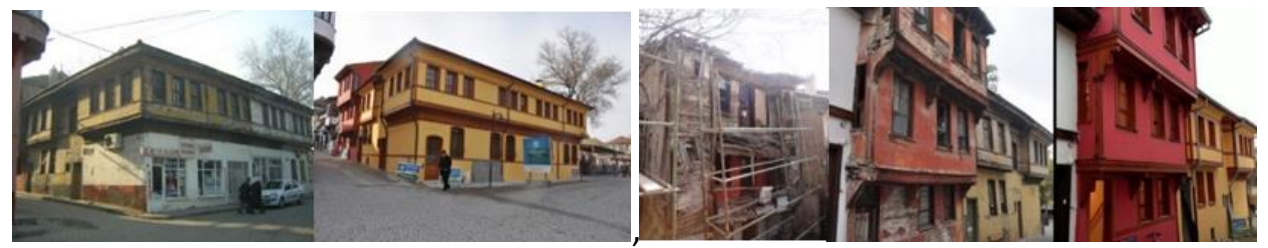

Şekil.28-Balkan Kültür Evi §

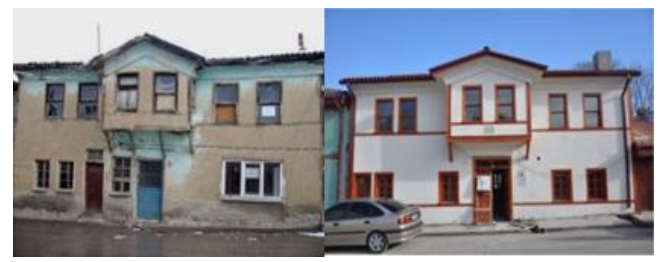

Restorasyonu yapılan Dede Mahallesi, Yeşil Efendi Sokak'ta yer alan bir diğer önemli konak Osmanlı Evidir. Konak, TBMM'nin 1. dönem milletvekili Halil ibrahim Efendi (Sipahioğlu) tarafından yaptırımıştır. Kurtuluş Savaşı zamanında Mustafa Kemal Atatürk'ü misafir etmesi ile ünlenen Osmanlı Evi 1880 - 1892 yılları arasında yaptııılmıştır. Odunpazarı bölgesindeki zengin süslemeleri ve ahşap işçiliği ile dikkat çeken önemli bir konaktır. Gerçekleştirilen restorasyon çalışmalarından sonra müze, restoran, butik otel olarak ziyarete açılmıştır. Restorasyonu yapılmış diğer önemli yapı Sivrioğlu Konağıdır. Konak 1900 tarihinde Sivrioğlu Kadı Ali Bey tarafından yaptırılmıştır. Restorasyon çalışmalarından sonra Türk Ocakları Eskişehir Şube binası fonksiyonu ile açılımıştır.

\footnotetext{
$\S$ Yapıların restorasyon öncesi ve sonrası görselleri Eskişehir Odunpazarı Belediyesi arşivinden alınmıştır.
} 
Şekil.29- Osmanlı Evi , Şekil.30-Sivrioğlu Konağı

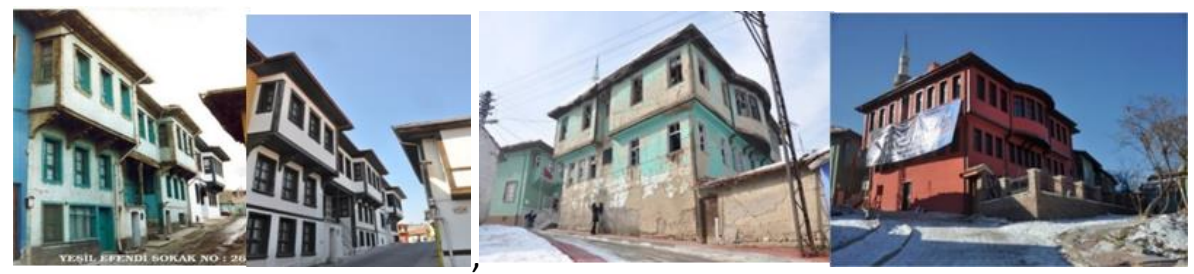

\subsubsection{Yağcızade Konağı Restorasyonu (Ataol Behramoğlu Kitaplığı)}

Yağcızade konağı Paşa Mahallesi Hacı Ebe Sokak'ta yer alan 265 yıllık tarihi bir konaktır. Konak yıkılmaya yüz tutmuşken kamulaştırılarak yeni bir fonksiyon eklenmiş ve Ataol Behramoğlu kütüphanesine çevrilmiştir. Restorasyon sonrasında iç mekân düzenlenmiş, kütüphane fonksiyonu amacına yönelik ufak değişikliklerle, kâr amacı gütmeyen bir mekân haline dönüştürülmüştür. Tamamen belediyenin kendi imkanlarıyla yaptığı bir restorasyon çalışması olan bu mekân daha öncesinde restoran olarak kiralanıp aslına uygun olmayan müdahalelerle zarar görmüştür. Bu çalışmada yapı yanlış müdahalelerden arındırılarak özgün haline dönüştürülmüş ve sonrasında kütüphane fonksiyonu verilerek hizmete açılmıştır. Konak ana mekânına sadece tefriş düzenlemeleri yapılmış, iç mekân düzenlemelerinde müdahale aslına uygun şekilde gerçekleştirilmiştir.

Şekil.31 - Yağcızade Konağı, Şekil.32- Yağcızade Konağı
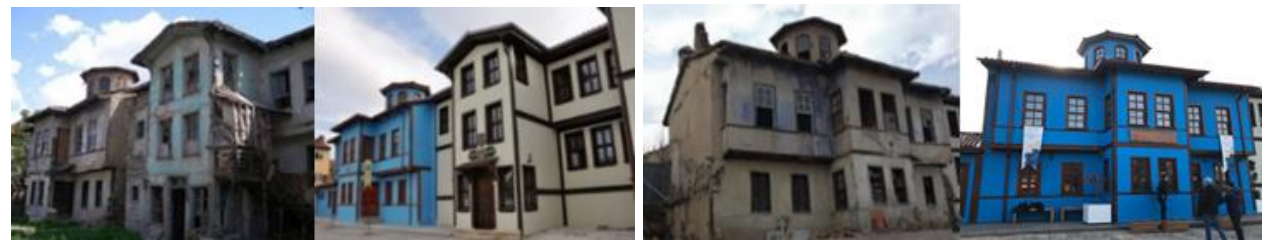

Restorasyon çalışmasına girdiğinde oldukça yıpranmış bir halde olan yapının zemin malzemesine ulaşılamadığı için benzer yeni nesil bir zemin malzemesi ile yenilenmiş ve taşıyıcı sistem, duvar ve merdiven onarımı yapılmıştır. Pencere önündeki izler öncesinde orada sedir benzeri bir oturma elemanı olduğunun ipucunu vermiş ve bu alana modern bir sedir tasarlanarak eylemsel bir atıfta bulunulmuştur. Konağın pencere açıklıkları değiştirilmeden onarılmış, aslına zarar vermeden temizlenmiş, kilit ve kapı kolu yenilenerek ve cilalanarak onarımı tamamlanmıştır. İç mekânda yapılan restorasyon çalışmaları öncesi ve sonrası Şekil.33, Şekil.34, Şekil.35, Şekil.36 ve Şekil.37'de verilmiştir. 
Şekil.33 - Yağcızade Konağı İç Mekân Rastorasyon Çalışmaları

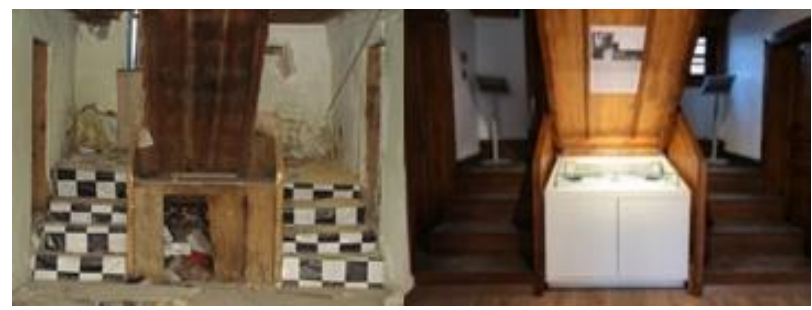

Şekil.34- Yağcızade Konağı Iç Mekân Restorasyon Çalışmaları

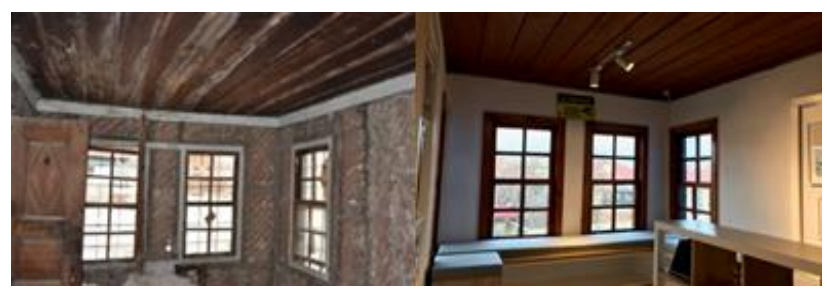

Şekil.35- Yağcızade Konağı lç Mekân Restorasyon Çalışmaları

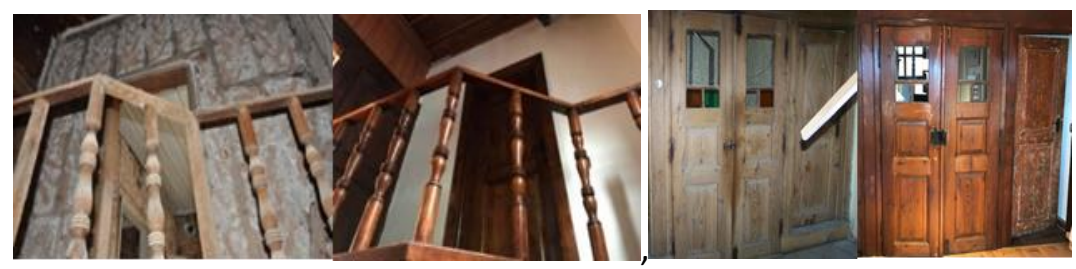

Şekil.36- Yağcızade Konağı l̇ç Mekân Restorasyon Çalışmaları **

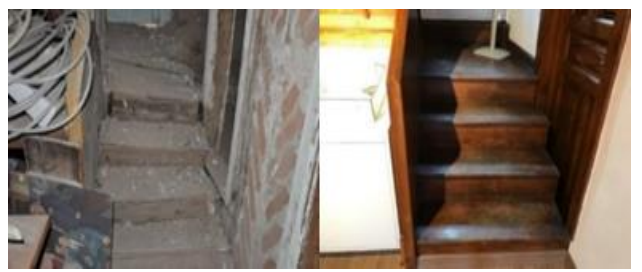

Restorasyon projelerinde önemli olan döndürülebilir uygulamalar yapmaktır. Özgün işlevi konut olan konağa kütüphane işlevi yüklenerek yeniden canlandırılmıştır. Fakat ilerleyen zamanlarda bu fonksiyondan vazgeçildiğinde ve tefrişler yapıdan çıkarıldığında, yapının korunmuş olması gerekmektedir. Bu amaç doğrultusunda Behramoğlu tarafından Odunpazarı Belediyesi'ne bağışlanan yaklaşık 7000 adet kitabın yer aldığı kütüphanedeki mobilyalar yapıya zarar vermeyecek

** Yapıların Restorasyon öncesi ve sonrası görselleri Eskişehir Odunpazarı Belediyesi arşivinden alınmıştır. 
şekilde konumlandırımış, kitaplıklar vida sistemiyle sıkıştırma yöntemi uygulanarak montelenmiş, mobilyalar yapıdaki hiçbir unsura zarar vermeyecek ölçülerde tasarlanmıştır. Ataol Behramoğlu Kitaplığı'nın restorasyon sonrası, günümüz durumu Şekil.38 ve Şekil.39 'da görülmektedir.

Şekil.38 ve Şekil.39-Yağcızade Konağı Restorasyon Sonrası (Günümüz) İç Mekân
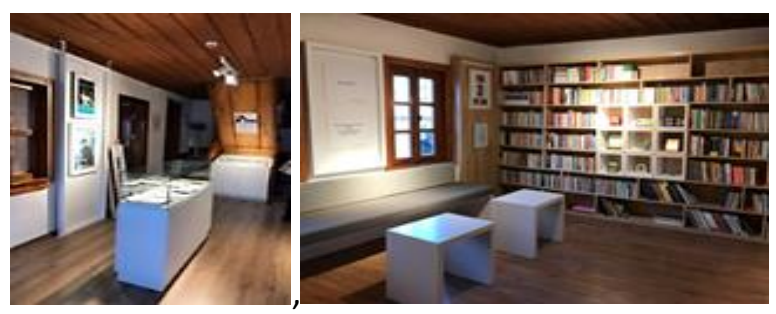

\subsubsection{Dalyancı Konağı Restorasyonu}

Akcami Mahallesi Dedelek Sokak'taki Osmanlı sivil mimari özelliğini koruyan 3 katı Dalyancı Konağı, Odunpazarı Belediyesi ile Eldem Kültür ve Sanat Vakfı ortaklığıyla restore edilerek Kültür ve Sanat Merkezi'ne dönüştürülmüştür. İç mekân restorasyonu oldukça büyük bir dikkatle gerçekleştirilmiş olan bu tarihi yapının duvarları temizlenerek sıvası tekrardan yapılmış, zemin kaplaması, merdiven ve kapıları temizlenerek zarar görmüş yerleri onarılmış ve cilalanarak iyileştirilmiştir. Konağın iç mekân restorasyonunun oldukça önemli olmasının sebebi ise konak duvarlarında boya ve sıva altından kalem işleri çıkmasıdır. Konağı konut olarak kullanan yapı sahipleri kalem işleri üzerini sıvayarak boyamışlar ve kalem işlerini kapatmışlardır. Bu önemli sanat eserleri büyük bir özenle temizlenerek gün yüzüne çıkarılmıştır. Konağın cephe restorasyonu Şekil.40 ve Şekil.41, iç mekân restorasyon çalışmaları Şekil.42, Şekil.43, Şekil.44, Şekil.45'de görülmektedir.

Şekil.40- Dalyancı Konağı

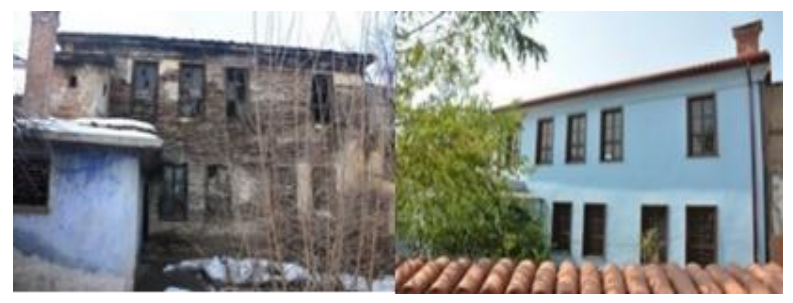


Şekil.41 - Dalyancı Konağı

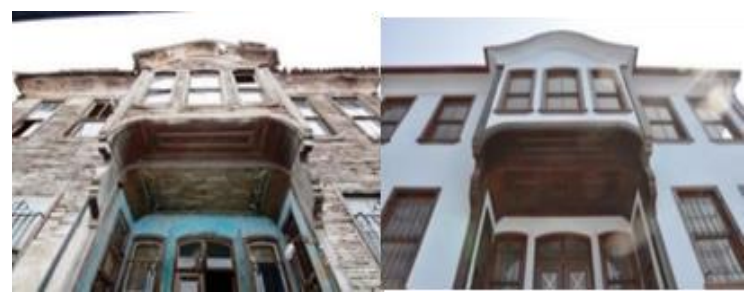

Şekil.42- Dalyancı Konağı İç Mekân Rastorasyon Çalışmaları

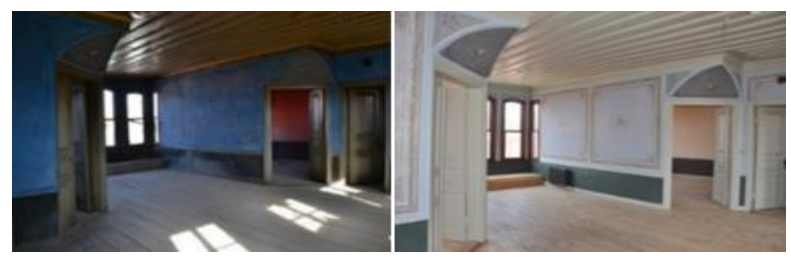

Şekil.43- Dalyancı Konağı İç Mekân Restorasyon Çalışmaları

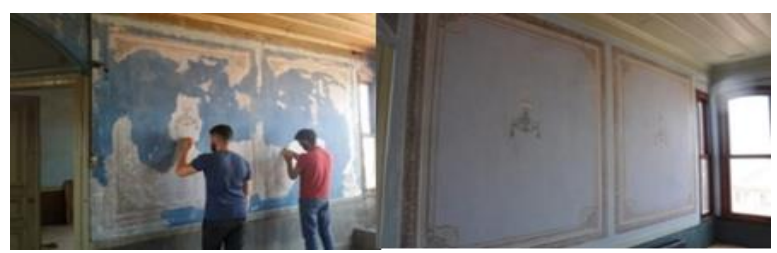

Şekil.44- Dalyancı Konağı l̇ç Mekân Restorasyon Çalışmaları

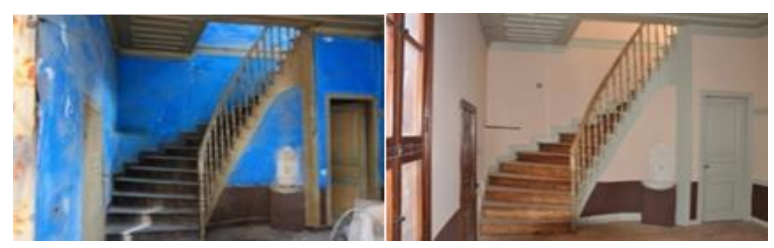

Şekil.45 - Dalyancı Konağı İç Mekân Restorasyon Çalışmaları

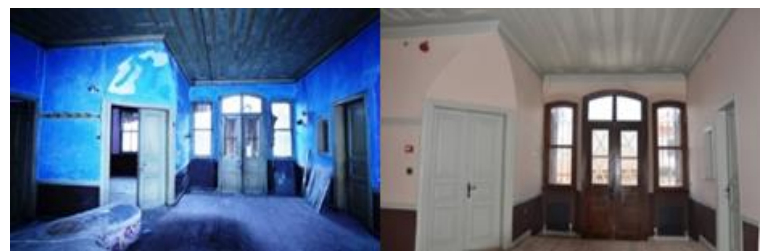


Şekil.46 ${ }^{+\dagger}$ - Dalyancı Konağı Restorasyon Sonrası (Günümüz) İç Mekân

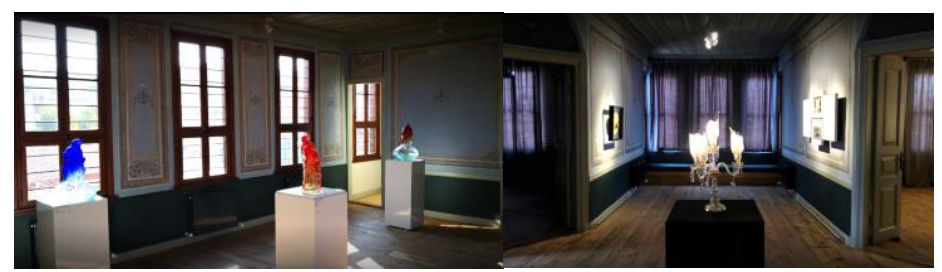

\subsubsection{Hafiz Ahmet Efendi Konağı Restorasyonu}

Yapılan restorasyon çalışmalarının en önemlilerinden bir diğeri Hafız Ahmet Efendi Konağı restorasyonudur. Restorasyon çalışmasında ilk yapıldığı dönemin ve bölgenin ana malzeme karakterine uygun olarak duvarlarda ahşap karkas kerpiç dolgu; pencere, kapı ve bunun dışındaki cephe elemanlarında ahşap kullanımıştır. Ana giriş kapısının sol tarafında ulunan ahşap bir merdivenle yukarı kata çıkımaktadır. Bu kat zemin kat planına paralellik göstermektedir. Zemin kattaki giriş ile beraber bu katın sofası öne doğru uzatılmıştır. Uzatılan bu kısmın güney cephesinde köşelere yerleştirilmiş iki pencere bulunmaktadır. Oda güney ve batı cepheye bakan ikişer pencere ile aydınlatılmaktadır. Restorasyon öncesi batı duvarında kare formlu tek pencere yer almakta iken ev sahiplerinden edinilen bilgiler doğrultusunda orijinalinde iki pencere olduğu tespit edilerek batı duvarına iki pencere yerleştirilmiştir. Bu katın yer döşemeleri ahşap plaka, tavan döşemeleri ise ahşap kirişleme şeklindedir (www.hafizahmetefendikonagi.com, 2020). Restorasyonu yapılan bu tarihi yapıya restorasyon ile beraber kafeterya fonksiyonu eklenmiştir.

Şekil.47- Hafız Ahmet Efendi Konağı Restorasyon Öncesi , Şekil.48 - Restorasyon Sonrası
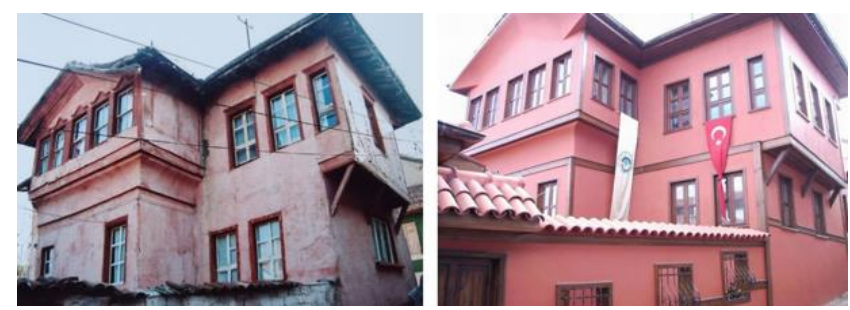

\section{Bulgular}

Yapılan araştırma ve incelemelerde Odunpazarı yerleşiminde bulunan konutların 4.1. Başlı̆ı altında belirtilmiş bulunan tarihi yapılarda sürdürülebilirliğin bütünleşik koruma ilkeleri doğrultusunda sahip oldukları özellikler tespit edilmiştir. Elde edilen bulgular bir tablo şeklinde Tablo- 2 'de verilmektedir. Gerçekleştirilen restorasyon çalışmalarının tümünde izlenen yol yapıların özgün planları üzerinde herhangi bir değişiklik yapılmadan, hatta yapılmış yanlış müdahaleler yapıya

\footnotetext{
${ }^{++}$Yapıların Restorasyon öncesi ve sonrası görselleri Eskişehir Odunpazarı Belediyesi arşivinden alınmıştır.
} 
zarar vermeden ortadan kaldırılarak, yapılar özgün haline döndürülmüştür. Yapıların var olan rölöveleri alınırken, restitüsyon projeleri çizilirken, restorasyon projeleri hazırlanırken ve restorasyon çalışmaları gerçekleştirilirken konuya hakim mimarlar, sanat tarihçileri ve akademisyenler ile çalışılmıştır. Bu çalışma sonucunda da yapılar zarar görmeden onarılmış, yeni fonksiyonlar yüklenmiş ve ölü bir bölge olan Odunpazarı Bölgesi canlandırılmış, bir sanat ve turizm merkezi haline getirilmiştir.

Tablo-2. İncelenen Örnekler ve Elde Edilen Bulgular

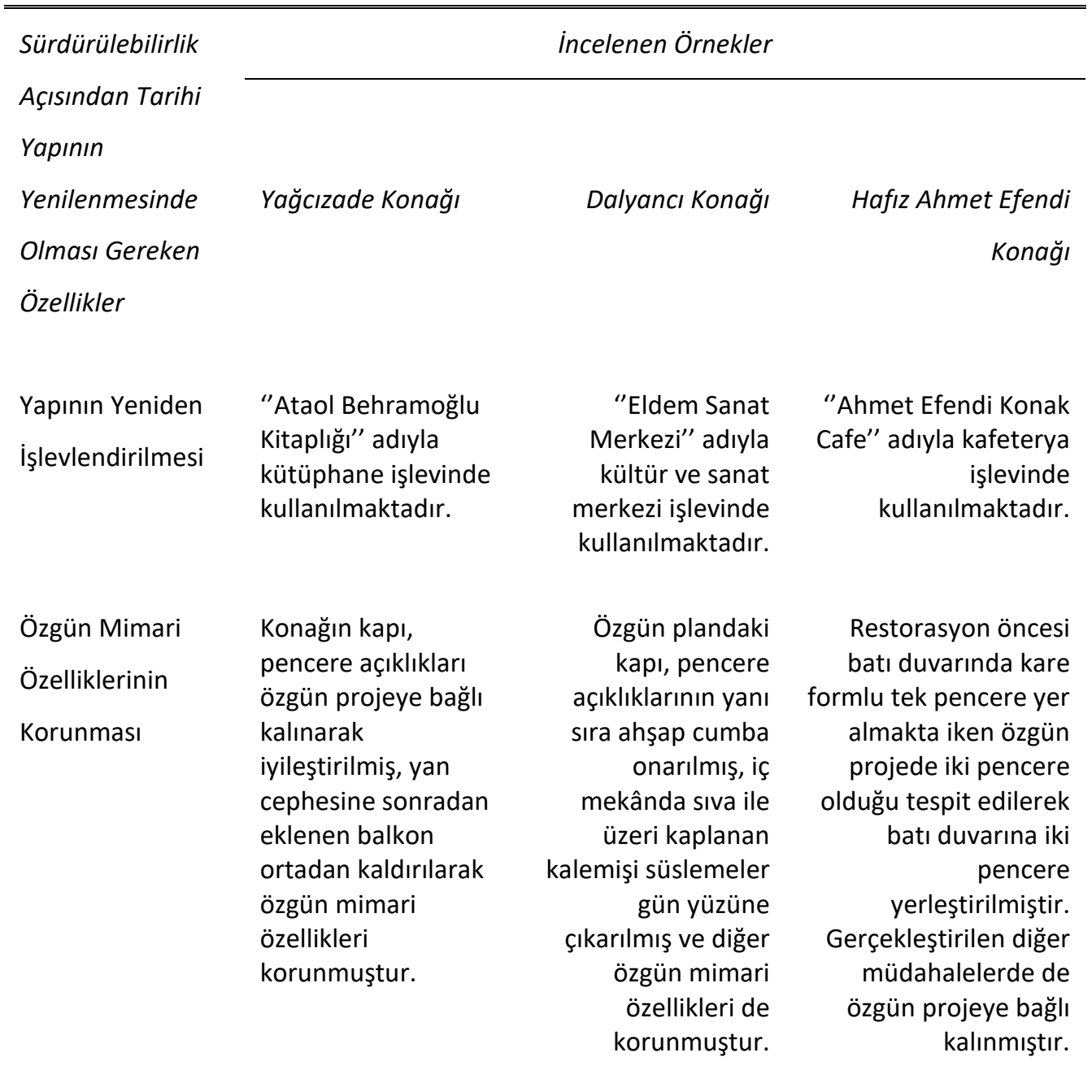




\begin{tabular}{|c|c|c|c|}
\hline $\begin{array}{l}\text { Özgün Plana } \\
\text { Uygunluk }\end{array}$ & $\begin{array}{l}\text { Çalışmalar özgün } \\
\text { plana bağlı kalarak } \\
\text { gerçekleştirilmiştir. }\end{array}$ & $\begin{array}{l}\text { Çalışmalar özgün } \\
\text { plana bağlı kalarak } \\
\text { gerçekleştirilmiştir. }\end{array}$ & $\begin{array}{r}\text { Çalışmalar özgün plana } \\
\text { bağlı kalarak } \\
\text { gerçekleştirilmiştir. }\end{array}$ \\
\hline $\begin{array}{l}\text { Yenileme ve } \\
\text { Onarım Sırasında } \\
\text { Mekânların } \\
\text { Malzeme } \\
\text { Kullanımı }\end{array}$ & $\begin{array}{l}\text { Yapının taşıyıcı } \\
\text { sistem, duvar ve } \\
\text { merdiven onarımı } \\
\text { özgün malzemenin } \\
\text { temizlenmesi ile } \\
\text { devam ettirilmiş olsa } \\
\text { da zemin } \\
\text { malzemesine } \\
\text { ulaşılamadığı için } \\
\text { yeni nesil bir zemin } \\
\text { malzemesi } \\
\text { kullanılmıştır. }\end{array}$ & $\begin{array}{r}\text { Duvarları } \\
\text { temizlenerek sıvası } \\
\text { tekrardan yapılmış, } \\
\text { zemin kaplaması, } \\
\text { merdiven ve } \\
\text { kapıların özgün } \\
\text { malzemesi } \\
\text { temizlenerek zarar } \\
\text { görmüş yerleri } \\
\text { onarılmış ve } \\
\text { cilalanarak } \\
\text { iyileştirilmiştir. }\end{array}$ & $\begin{array}{r}\text { Ana malzeme } \\
\text { karakterine uygun } \\
\text { olarak duvarlarda } \\
\text { ahşap karkas kerpiç } \\
\text { dolgu; pencere, kapı } \\
\text { ve bunun dışındaki } \\
\text { cephe elemanlarında } \\
\text { ve zemin } \\
\text { kaplamalarında özgün } \\
\text { malzemeye uygun } \\
\text { olarak ahşap malzeme } \\
\text { kullanılmıştır. }\end{array}$ \\
\hline $\begin{array}{l}\text { Mekânların } \\
\text { Donatı } \\
\text { Elemanlarının } \\
\text { Korunması }\end{array}$ & $\begin{array}{l}\text { Zemin ve duvardaki } \\
\text { izlerin öncesinde } \\
\text { sedir oturma elemanı } \\
\text { olduğunun ipucunu } \\
\text { vermesi ve alana bir } \\
\text { sedir } \\
\text { konumlandırılması } \\
\text { örneğinde olduğu } \\
\text { gibi donatı } \\
\text { elemanlarının yerleri } \\
\text { korunmuş, zaman } \\
\text { içerisinde yok olan } \\
\text { donatı elemanların } \\
\text { ise yerleri tespit } \\
\text { edilip yeniden } \\
\text { konumlandırılmıştır. }\end{array}$ & $\begin{array}{r}\text { Var olan donatı } \\
\text { elemanlarının } \\
\text { bakım ve onarımı } \\
\text { yapılarak donatı } \\
\text { elemanları aynen } \\
\text { korunmuştur. }\end{array}$ & $\begin{array}{r}\text { Var olan donatı } \\
\text { elemanlarının bakım ve } \\
\text { onarımı yapılarak } \\
\text { donatı elemanları } \\
\text { aynen korunmuştur. }\end{array}$ \\
\hline
\end{tabular}




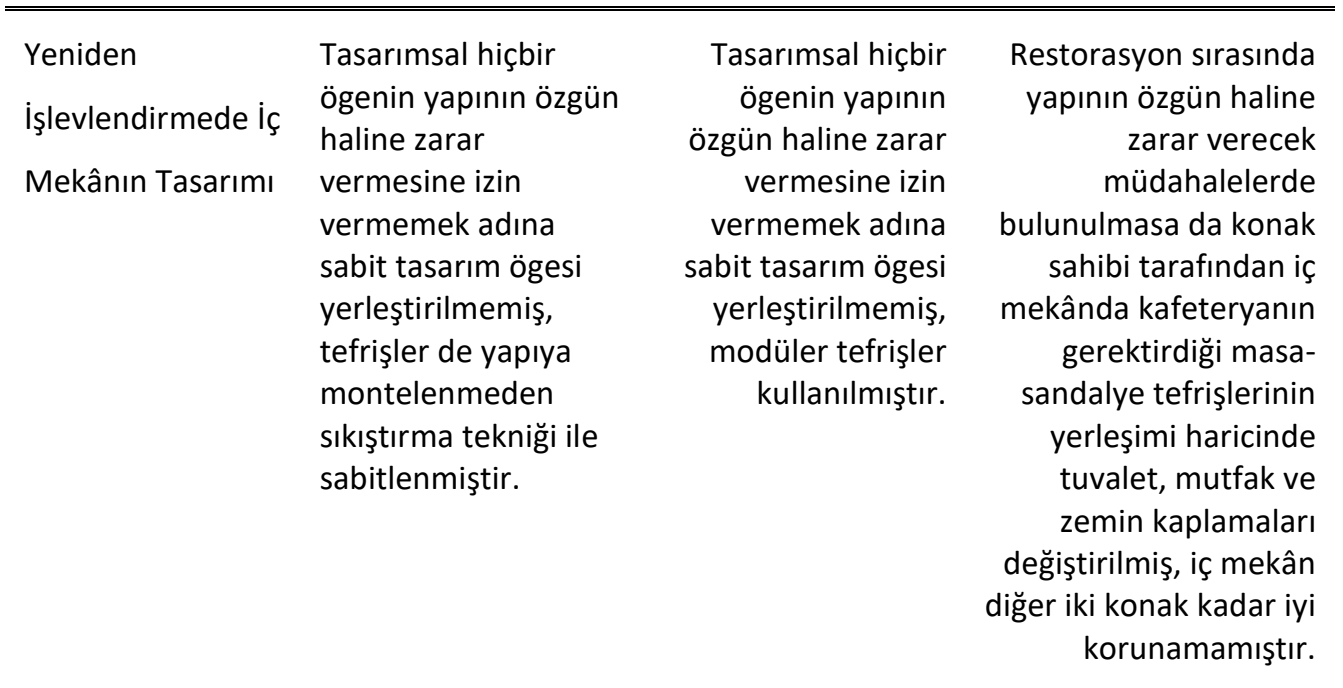

\section{Sonuç}

Farklı kültürlere ve uygarlıklara ev sahipliği yapmış, geçmiş ile gelecek arasında köprü görevi gören tarihi yapıların sürdürülebilirliğini, yani gelecek nesillere bozulmadan aktarılmasını sağlamak tüm toplumlar için oldukça önemli bir görevdir. Toplumların varlığını sürdürmesinde büyük bir önemi olan tarihi yapılarda sürdürülebilirliğin sağlanması adına eğitim, koruma, sürekli bakım, yenileme ve restorasyon uygulamalarının işinin ehli kişiler tarafından yapılması en temel unsurlardan biri olup koruma ve yenileme çalışmalarında gerekli özen gösterilmediğinde vahim sonuçların doğduğu açıkça görülmektedir. Tarihi yapılarda sürdürülebilirliğin sağlanması adına bu çalışmada belirlenen yöntemlerle birlikte Eskişehir'in tarihi, kültürel ve mimari kimliği için oldukça önemli olan, şehrin ilk yerleşim yeri Odunpazarı bölgesinde bulunan tarihi Odunpazarı Evleri kapsamında 2005 yılında başlayan restorasyon çalışmaları incelenmiştir. İncelemenin temel amacı böylesine önemli tarihi yapıların restorasyon sürecinde izlenen yolun farkındalığında olmak, müdahalelerin doğru yapılıp yapılmadığına ilişkin bir sonuca ulaşmaktır. Bu amaç doğrultusunda Niteliksel Araştırma Yöntemleri kullanılarak incelenen Odunpazarı Evleri restorasyon çalışmalarının temel amacı; bir dönem çok popüler olmasına karşın bir takım siyasi ve kültürel olayların etkisiyle metruk ve ölü bir bölge haline gelerek saygınlığını yitiren Odunpazarı Evleri’nin saygınlığını yeniden kazanmasıdır. "Odunpazarı Evlerini Yaşatma Projesi" kapsamında Kültür Bakanlığı, Anadolu Üniversitesi Mimarlık Bölümü, Vakıflar Genel Müdürlüğü ve sivil toplum kuruluşlarının desteği ile gerçekleştirilen proje amacına ulaşan bir çalışma olsa da saygınlı̆̆ını yeniden kazanan bölgede restorasyon çalışmaları sonrası eski atmosferin yakalanmaması, işlevlendirme ve işlevlendirme sonrası uzun süreli kullanımla beraber yapıların zarar görmesi gibi bazı durumların da oluştuğu tespit edilmiştir. Gerçekleştirilen restorasyon çalışmalarının tümünde izlenen yol yapıların özgün planları üzerinde herhangi bir değişiklik yapılmadan, hatta sonradan yapılmış bir müdahale varsa bu müdahaleler yapıya zarar vermeden ortadan kaldıılarak, yapıları özgün haline döndürmektir. 
Yapıların var olan rölöveleri alınırken, restitüsyon projeleri çizilirken, restorasyon projeleri hazırlanırken ve restorasyon çalışmaları yapııırken mimarlar, sanat tarihçileri ve akademisyenler ile çalışılmıştır. Bu çalışma sonucunda da yapılar zarar görmeden onarılmış, yeni fonksiyonlar yüklenmiş ve ölü bir bölge olan Odunpazarı Bölgesi canlandırılmış hatta önemli bir sanat ve turizm merkezi haline getirilmiştir. Çalışma yöntemi ve doğru müdahalelerin yanı sıra finansman olarak da öncelik hibe destekleri yönünde olan, belediye kaynaklarını mümkün olduğunca kullanılmadığı bu projede sokak sakinleri, hiçbir maddî talepte bulunmadan, projenin tüm aşamalarında, sürekli eğitim ve bilinçlendirme faaliyetleri ile desteklenmiş̧ir. Ancak bu bilgilendirme sürecinin üzerinden zaman geçtikçe yeniden işlevlendirilen tarihi yapılardan bazılarının işletmecileri tarafından yapılara zarar verildiği görülmektedir. Gerçekleştirilmiş restorasyon çalışmaları Tarihi ve Kültürel Mirası Koruma Proje ve Uygulamalarını Özendirme Yarışması kapsamında "Tarihi Kentler Birliği Süreklilik Ödülleri”ne layık görülmüştür. Restorasyon çalışmalarından sonra adını duyuran Odunpazarı Kentsel Sit Alanı 2012 yılında da UNESCO Dünya Kültür Mirası Geçici listesinde de yerini almıştır.

\section{Araştırma ve Yayın Etiği Beyanı}

Bu makale için etik kurul izni alınmasına gerek yoktur.

Yazarların Makaleye Katkı Oranları

Rümeysa Reyna Erşan: \%50 , Doç.Dr.Deniz Demirarslan: \%50

\section{Çıkar Beyanı}

Yok.

\section{Kaynaklar}

Altınsapan, E. ve Tulum, M. (2016), Eskişehir Kurşunlu Cami Kitabesinin Tarihlendirilmesi Üzerine Son Tespit, Akademik Sosyal Araştırmalar Dergisi, 4(23), 1-6

Arsan, Z. (2008), Türkiyede Sürdürülebilir Mimari, Mimarlık Dergisi 340, 21-30.

Atıcı, E. (2017), Eskişehir Odunpazarı Evlerinin Cephe Dili Üzerinden İncelenmesi, Sanat Tarihi Dergisi, 26(1), 1-26.

Aydın, A. ve Şahin, Ö. (2018), Tarihi Yapıların Yeniden İşlevlendirilmesi: Isparta Aya İshotya (Yorgi) Kilisesi'nin Gül Müzesi'ne Dönüşümü, Türkiye Bilimler Akademisi Kültür Envanteri Dergisi, (17), 63-75.

Ballı, A. (2019), Sürdürülebilirlik, Sürdürülebilir Girişimcilik, Türkiye'de Sürdürülebilir Girişimcilik, Mehmet Akif Ersoy Üniversitesi Sosyal Bilimler Enstitüsü Dergisi, 11(29), 464-483.

Bektaş, C. (2013), Türk Evi, İstanbul: Yem Yayınları.

Değirmenci, i̇. ve Sarıbıyık, M. (2015), Tarihi Mekanlarda Sürdürülebilirlik Bağlamında Cittaslow Hareketi: Taraklı Örneği, Gazi Üniversitesi II. Uluslararası Sürdürülebilir Yapılar Sempozyumu , 612-620. 
Karasözen, R. ve Koca, G. (2012) , Transformation of Traditional Ottoman Neighbourhoods - A Case Study in Odunpazarı - Eskisehir, International Journal of Arts \& Sciences, 2(5) ,1-7.

Mahrebel, H. (2006), Tarihi Yapılarda Taşıyıcı Sistem Özellikleri, Hasarlar, Onarım Ve Güçlendirme Teknikleri, İstanbul Teknik Üniversitesi Fen Bilimleri Enstitüsü, Yüksek Lisans Tezi, İstanbul.

Nalçakan, M. (1993), Tarihi ve Kültürel Sürekliliğin Fiziksel Çevrede Değişime Yansıması ve Eskişehir Örneği, İstanbul Teknik Üniversitesi Fen Bilimleri Enstitüsü, Doktora Tezi, İstanbul.

Öztürk, A.Ç. (2016). Eskişehir' in Geçmişteki ve Bugünkü Kent Belleğinin Zihin Haritaları Üzerinden Okuma Denemeleri, Ideal Kent Dergisi, 7(20), 856-880.

Özüdoğru, Ş., Ertuğrul ,Z. ve Manaz ,S. (2005), Eskişsehir Odunpazarı ve Sivrihisar Evlerinin Cephe Örnekleri, Eskişehir: Anadolu Üniversitesi Edebiyat Fakültesi Yayınları.

Sev, A. (2009), Sürdürülebilir Mimarlık, İstanbul: Yem Yayınları.

Şen, H. Kaya ve A. Alpaslan, B. (2018), Sürdürülebilirlik Üzerine Tarihsel ve Güncel Bir Perspektif, Gazi Üniversitesi Ekonomik Yaklaşım Derneği, 29(107), 1-47.

Tanrısever ,C., Saraç, Ö. ve Aydoğdu, A. (2016), Yeniden İşlevlendirilen Tarihi Yapıların Sürdürülebilirliği , iktisat ve Girişimcilik Üniversitesi Türk Dünyası Kırgız - Türk Sosyal Bilimler Enstitüsü Dergisi , (54), 1068-1082.

Uçkan, Y. ve Uçkan E. (2002), Odunpazarı Evleri, Eskişehir: Odunpazarı Belediyesi Yayını.

Yüksel,G. Kurtçu,H., Koçak,M. ve Aksoy,R. (2015), Şehrimiz Eskişehir, Eskişehir.

Zeren, M.T. (2019), Tarihi Çevrede Yeni Ek ve Yeni Yapı Olgusu, İstanbul: Yalın Yayıncılık.

(2011), Eskişehir Odunpazarı Kentsel Sit Alanı Koruma Amaçlı Imar Planı Revizyonu, Özkut,Deniz ve Rıza Yılmaz (Ed.), Eskişehir: Odunpazarı Belediyesi Yayını.

Internet Kaynakları

https://arkeofili.com/gaziantepteki-roma-koprusunun-yerine-yenisi-yapildi/ET:2019

https://eskisehir.ktb.gov.tr/TR-149936/odunpazari-evleri-odunpazari-kentsel-sit-alani.html ET:2019

http://www.hafizahmetefendikonagi.com/index.php/139-2/ET:2020

http://www.mustafacambaz.com/details.php?image id=24010 ET:2020

http://sinemakultur.com/index.php/2018/07/25/unesconun-mirasi-odun-pazari/ET:2020

https://tr.sputniknews.com/cevre/201508261017347994/ET:2020 